University of Rhode Island

DigitalCommons@URI

Open Access Master's Theses

1981

\title{
THE BEHAVIOR OF RURAL LANDOWNERS IN RESPONSE TO LOCAL ECONOMIC DEVELOPMENT: THE CASE OF WEST GREENWICH, R.I.
}

John C. Cronin

University of Rhode Island

Follow this and additional works at: https://digitalcommons.uri.edu/theses

\section{Recommended Citation}

Cronin, John C., "THE BEHAVIOR OF RURAL LANDOWNERS IN RESPONSE TO LOCAL ECONOMIC DEVELOPMENT: THE CASE OF WEST GREENWICH, R.I." (1981). Open Access Master's Theses. Paper 479.

https://digitalcommons.uri.edu/theses/479

This Thesis is brought to you for free and open access by DigitalCommons@URI. It has been accepted for inclusion in Open Access Master's Theses by an authorized administrator of DigitalCommons@URI. For more information, please contact digitalcommons-group@uri.edu. 
THE BEHAVIOR OF RURAL LANDOWNERS

IN RESPONSE TO LOCAL ECONOMIC DEVELOPMENT:

THE CASE OF WEST GREENWICH, R.I.

A RESEARCH PROJECT SUBMITTED IN

PARTIAL FULFILLMENT OF THE REQUIREMENTS

FOR THE DEGREE OF MASTER OF COMMUNITY PLANNING

UNIVERSITY OF RHODE ISLAND

1981 
MASTER OF COMMUNITY PLANNING

RESEARCH PROJECT

$\mathrm{OF}$

JOHN C. CRONIN

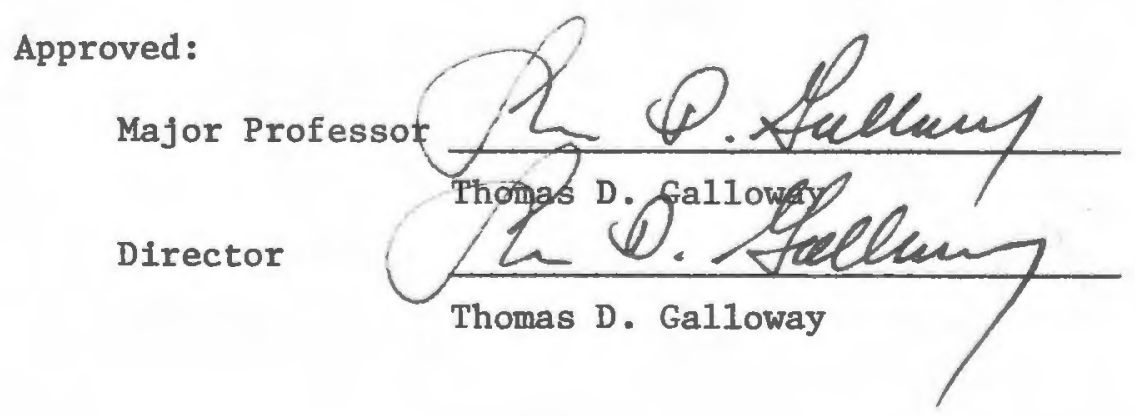




\section{ACKNOWLEDGEMENTS}

Many people have contributed to the conduct of this research. I am indebted to the public employees of the Town of West Greenwich for their cooperation. Foremost among them are Town Clerk Cora M. Lamoureaux, Tax Assessor Henry B. Wright, and Tax Assessor's C1erk Madeline L Briggs. who contributed much time and assistance, as well as access to maps and back records, for which I am grateful. I also extend my sincere appreciation to Professor Thomas D. Gallowayfor his interest, advice and critical appraisal of the research.

An effective ownership study logically requires the support of the property owners being examined. Local landowners are naturally concerned when anyone, expecially an outsider, proposes to study who owns what pieces of land and why. The survey respondents took the time and effort to reveal confidential information to me. Their contribution has been appreciated and I took specific steps to preserve their privacy.

I would also like to thank my wife, Diane and my two sons, Keith and Sean, for having patience and giving me their love and support throughout this study.

A final acknowledgement is due Susan Russell, and Carol DeSalvo, who were responsible for the typing of this report. 


\section{TABLE OF CONTENTS}

$\begin{array}{ll}\text { CHAPTER PAGE } & \text { PAT }\end{array}$

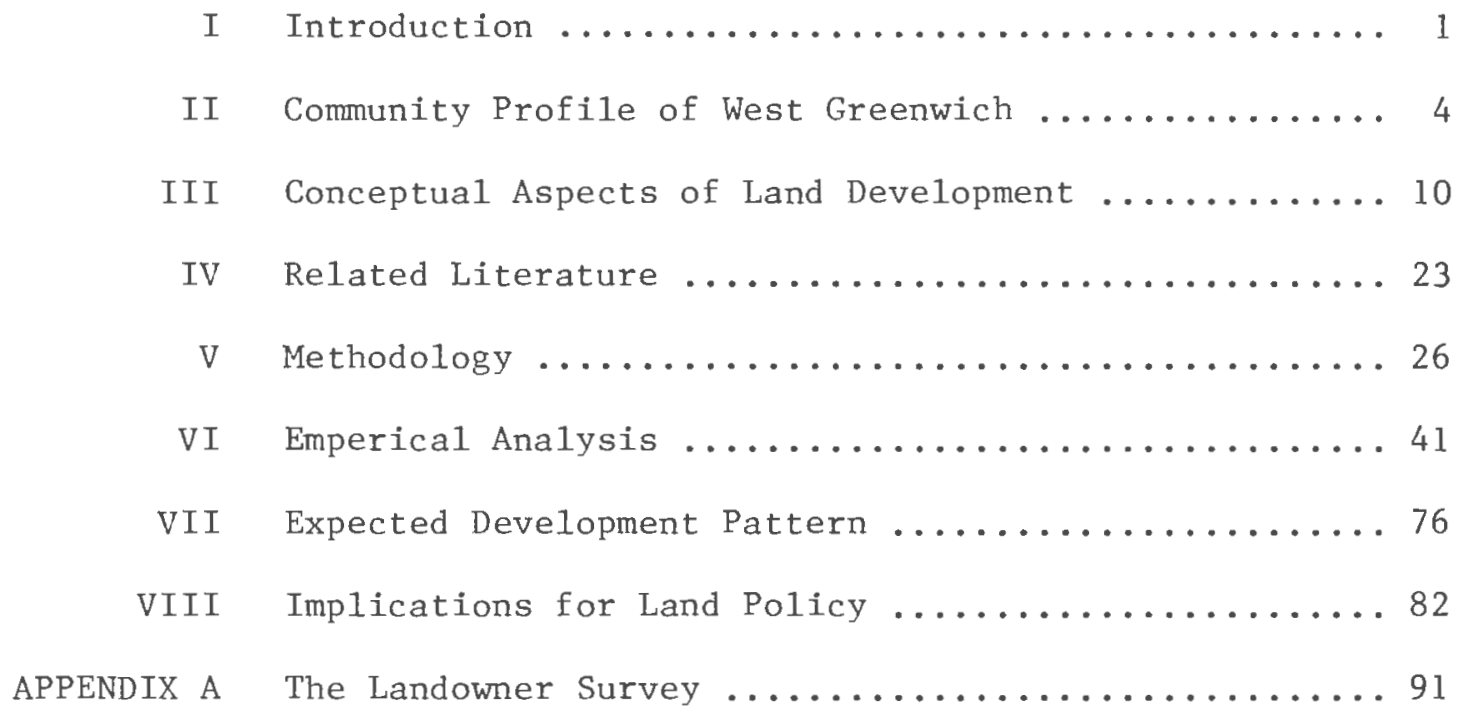


Map

Number

Title

Page

1.

Rhode Island Major Highway System ......... 5

2 .

West Greenwich Surface Water Systems

and Road Network ................... 7

3.

West Greenwich Development Pressures ......... 
Figure

Number

Effective Land Supply $\ldots \ldots \ldots \ldots \ldots \ldots \ldots \ldots$

2.

Land Demand

3.

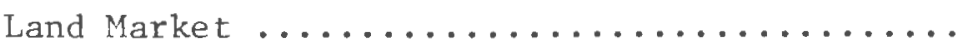

4 .

Effect of Increasing Demand

5.

Composite Effect of Economic Development ..... 19

6.

Size of Land-Holding $\ldots \ldots \ldots \ldots \ldots \ldots \ldots . . . .$.

42

7.

Form of Ownership $\ldots \ldots \ldots \ldots \ldots \ldots \ldots \ldots$

43

8 .

Length of Ownership

44 
Table

Number

Title

$\underline{\text { Page }}$

1. Frequency Distribution of Owner and Property Characteristics

2

Landowner Response to Digital Development

3. Landowner Response to Community Development

54

4.

Landowner Response to Policy Choices

5.

Significant Correlation Coefficients of Total

Response to Policy Issues Concerning Community

Development

6. Landowner Response to the Influence of Development Factors or Current Land Use

7. Percentage of Land in Rural Use

9. Landowner Ranking of Factors Which Could Help Retain Land in its Present Use

9. Group Means of Factors Which Could Help Retain Land in its Present Use

10. Significant Correlation Coefficients of Total Response to Influence of Development Factors on Current Land Use

11. Frequency Distribution of Landowner Classification

12.

Significant Correlation Coefficients of Landowner Scales with Property and Owner Characteristics 
INTRODUCTION

Rhode Island, like most of the United States, has experienced a shift in population and settlement patterns from the central city to less developed suburban and rural communities. This pattern within the state is expected to continue and to be amplified by an industrial extension of development which follows the major inter-state highway south to West Greenwich. This area has the lowest population density in the state. Digital Equipment Corporation, the world's largest maker of minicomputers, is expected to construct a new facility in this area on a 147 acre site acquired from the state Port Authority and Economic Development Corporation for $\$ 1,673,314$. (Providence Journal 7/29/80).

The State acquired the land in October of 1978 for ten thousand dollars per acre to forestall speculation and/or the increase in land value until such time as Digital could finalize the plan to locate in Rhode Island (Providence Journal $7 / 2 / 80$ ). In addition to an attractive price, the State gave Digital a strong commitment to public improvements. The State's entire 1978 federal public works allotment, $\$ 3.9$ million, was used to extend sewers to the site. A project to provide better access to this site is underway costing three million dollars, which will build a Route 95 interchange at Hopkins Hill Road (Evening Bulletin 4/16/81). The State's policymakers obviously expect Digital to provide a significant boost to the state's economy.

The new facility will be designed for research, engineering and administrative purposes. It is expected to employ up to 700 persons within a year after its projected completion in late 1983 (Evening Bulletin 4/16/81). The location of Digital establishes a new node of employment which may lead to further development. The Town of West Greenwich has proposed to rezone 100 acres on the west side of Hopkins Hill Road from farming-residential 
to industrial (Evening Bulletin 1/16/81). Satellite companies and service firms are expected to capitalize on the opportunities initiated by Digital and supportive public policies. Demand for residential development is likely to increase in the surrounding areas.

Clearly, the market demand for residential, commercial, and industrial purposes will compete for land which is presently allocated to rural uses. This process of urban growth has been condemned for the unnecessary loss of agricultural land, timber stands, and open space, the ugliness of sprawled development and its inefficiency (e.g. Clawson 1962, Real Estate Research Corporation 1974, Wallace 1970, Whyte 1968). On the other hand, proper management of rural development can renew and enhance the quality of life in rural towns (Foster 1981, Barber et al 1980, Bendavid-Val 1980).

Local policymakers are faced with the challenge to formulate and evaluate measures which address problems and opportunities associated with urban expansion. Implementation of public plans for retaining open space or, conversely, for bringing land into development would be facilitated by a better understanding of those factors which affect sales decisions. Land ownership characteristics can contribute to our understanding of which land use regulations and policies are likely to work.

As a contribution to such understanding, a study has been made of the characteristics of both rural land and its ownership in West Greenwich. The study universe included all 177 parcels of ten or more acres in West Greenwich as of November, 1981. Property characteristics were determined by a logical analysis of environmental constraints and land use conflicts through the use of overlay land use planning maps of West Greenwich. Landowner characteristics were determined by a search through the public records and a survey of individual owners. An indicator of 1 and development probability was theri calculated for each farcel. 
The purpose of this study is to generate new knowledge about the Town of West Greenwich. The findings of this study, due to its limited scope and size of sample, may not be generalizable for use in other areas. Nonetheless, it is hoped that this study's findings will contribute to an understanding of urban fringe land tenure for a rural town undergoing economic development.

After a brief introduction to the community of west Greenwich, the underlying concepts of this study are explained with a description of the dynamics of non-metropolitan industrialization. This report will then review the literature concerning landowner behavior in the urban fringe in order to determine its relevance for this study. The methodology of this study will be explained in the subsequent section along with a description of the landowner survey. Following the formulation of the hypotheses will be a presentation of the empirical analysis. A forecast of private land use decisions will ther be used to suggest policy recommendations. 
On June 30, 1709 a group of thirteen men purchased 35,000 acres of the "Vacant Land Tract" to the west of the Town of East Greenwich. This tract is located 20 miles southwest of Providence as shown on Map 1. In 1741, the area separated from East Greenwich and became incorporated as the Town of West Greenwich. The population increased steadily during the 18 th century. Farming and lumbering became the main occupations of the townspeople. The settlers were a hardy and handy lot accustomed to hard work and the use of the gun and axe.

The population stabilized after the Revolutionary Period until about 1840 (Comprehensive Community Plan of the Town of West Greenwich 1972). The mid-19th century was a time of very rapid population increase due to increasing employment opportunities in manufacturing. From 1880 to 1920, the collapse of manufacturing activities contributed to the considerable decline in population to a low of 367 (R.I. Dept. of Economic Development 1977). There was a slow increase after this low population period. The Great Depression accelerated the rate of growth but substantial gains in population did not occur until after World War II. As the pace of suburbanization increased between 1950 and 1980, West Greenwich showed a population increase of 223 percent. The population of West Greenwich in 1980 was 2,738. (Bureau of the Census 1950-1980). Projections by the R.I. Statewide Planning Program estimate the town's population to be 3,300 in 1985 and 3,700 in 1990.

According to the 1980 census, there was a total of 1,008 housing units in the town. This increase of 246 dwelling units over 1970 represents a rate of growth of 32.3 percent, which ranks fifteenth among the thirty-nine cities and towns in the state for percent change over the 


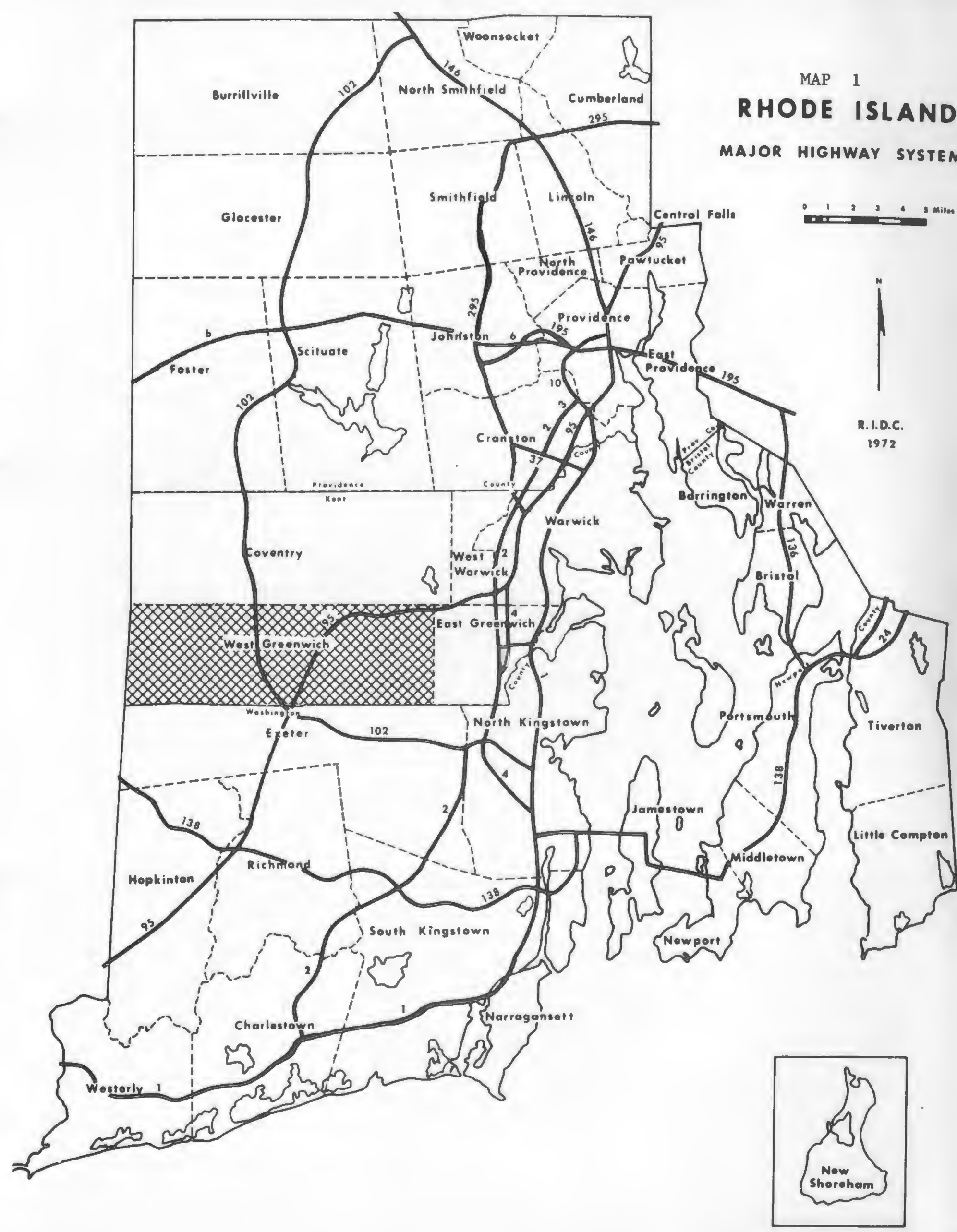


past decade. The number of building permits issued for single family homes in the first nine months of 1981 was 19, a number equal to the permits issued in the first nine months of 1980 (R.I. Builders Association 1981). This relatively low level of new unit authorizations reflects the depressed situation in the building industry due to high interest rates. Residential growth has taken place in the Mishnock area, along Weaver Hill Road, Victory Highway, Plain Meeting House Road, Breakheart Hill Road, Sharp Street, John H. Potter Road, and Robin Hollow Road.

Map 2 shows the 82 miles of streets and highways in West Greenwich (R.I. Dept. of Transportation 1976). Approximately 20 miles are unpaved. ${ }^{1}$ The state owns and maintains about 26 miles of main routes.

The town is governed by a five member town council headed by an appointed council president. The Rhode Island Department of Community Affairs in cooperation with the West Greenwich Planning Board has developed a Comprehensive Community Plan. The planning board has also developed a set of subdivision regulations. Most of the town is zoned rural-residential. The minimum lot size allowed for development is two acres and the minimum street frontage is 200 feet. There are no public sewers. Most residents receive their water from their own wells. ${ }^{2}$ service is also available from the Kent County Water Authority.

The economic base of the town is provided by the lumber industry, manufacturing (American Welding Company, Mishnock Lace Inc., and Precision Screw Products), the beverage industry (Coca-Cola), and farming. According to the most recent census figures, the median family income for the town was $\$ 9,796$ in 1969. The median family income for Kent County, which includes West Greenwich as well as four other communities, was $\$ 10,705$ in 1969 (Bureau of Census 1970). 


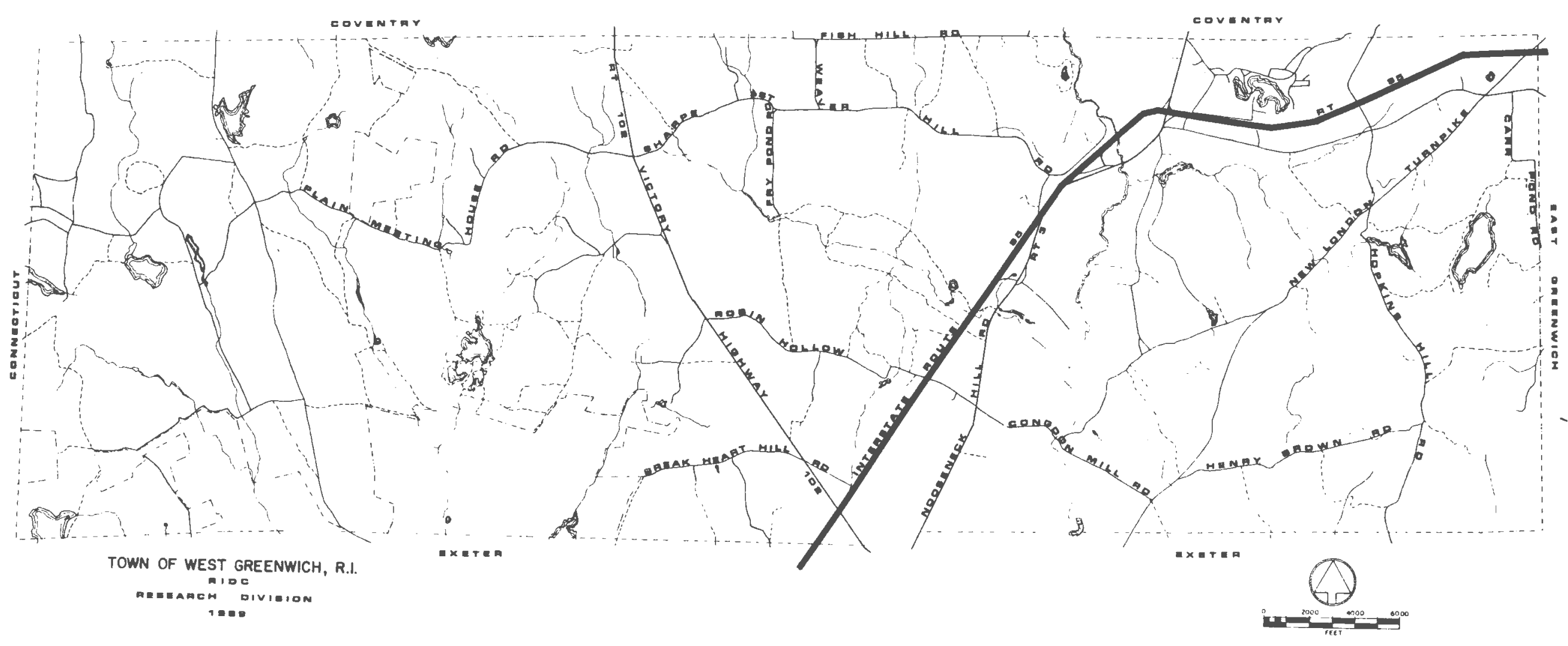

MAP 2

West Greenwich Surface Water Systems and Road Network 
West Greenwich remains the most sparsely populated area in the state with a population density of 54 people per square mile. The town has a total land area of 50.6 square miles. About one-third of the town's total land area is state owned for parks and recreation or for future development. The W. Alton Jones Campus of the University of Rhode Island which has 2,300 acres is located in the town and is used as a research facility, conference and a youth science center and a camp.

In 1962, the State of Rhode Island obtained land in and around the Big River and Wood River areas in West Greenwich. The acquisition is to be eventually developed into a large reservoir. The entire plan is long range and for the most part only preliminarily developed. Residents within the area lease the land from the state. Some dairy and poultry farming and gravel removal from the future reservoir site is taking place. The rural community is known for its natural woodlands, ponds and streams which are ideal for recreation purposes. Historically, it was the favorite hunting grounds of the Narragansett Indians and remains one of the better hunting areas in Rhode Island due to its ecological diversity. Fresh water fishing is available on Breakheart Brook, Flat River, and Big River. Lake Mishnock provides a privately owned swimming and recreation area. Wickaboxet Management Area and portions of Arcadia Management Area and Beach Pond State Park are located in town. The area is also blessed with fine riding trails, scenic views, unusual rock formations, sand dunes and historic sites.

The low population density has provided for the rural amenities, but it has also hindered the development of urban conveniences. For example, residents do not have a local post office. West Greenwich contains few stores and has no financial institutions. Residents utilize the banking and shopping facilities of the nearby communities of Coventry, 


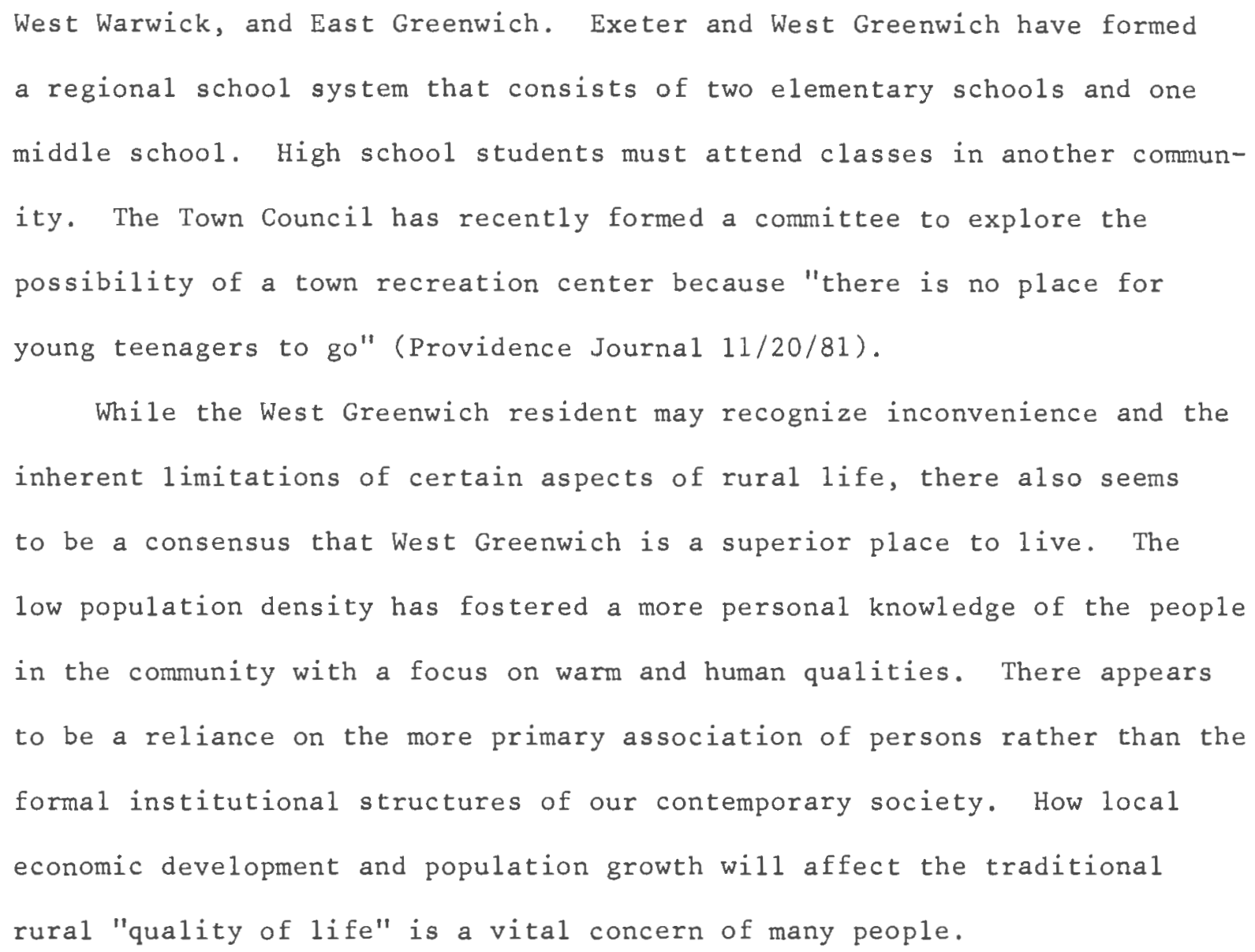


Industrial growth in West Greenwich is a planned structural rearrangement of land resource allocation. State and local policymakers have coordinated their activities with the Digital Equipment Corporation in order to convert idle land into industrial property. This development affects the environmental, social, and economic circumstances of the use of land in the region. Each landowner cannot avoid experiencing a change and $c$ annot plan his own land use as if it will not happen. The new circumstances may change the landowner's thinking about his or her own land use plan. In this sense, the landowner may be influenced to modify old plans with new ones.

Presumably, each of the relevant individuals and groups within the community have and/or will assess the development according to their own criteria of potential costs and benefits. They can be expected to carry on activity in the arena of political economics to maximize their benefits and minimize their costs. However, real inequalities may exist among the impacted parties with respect to distributed benefits and costs. The assessments of the development by landowners will depend upon how the resulting process of land use changes compliment or conflict with the owner's plan for his or her particular unit.

A. MOTIVE AND COMPLIMENTARITY

Plans for the use of 1 and resources within each 1 and unit take their cue from the motive which prompts the holder of the unit to have and to hold it. ${ }^{3}$ The motives of different owners may be in sympathy with each other and one may help the other by an adjustment of boundaries, granting of easements, exchange of equipment, and/or continued maintenence of property character form. Motives are often in conflict, as when the land 
resources of one unit adversely affect what is or could be done on the other.

The important factor for West Greenwich landowners is how the new development by Digital will compliment, conflict or be neutral toward their own particular land use plans. The measure of complimentarity will depend upon each landowner's motive for using his or her land and the presence of net fiscal gains to the community. These are some indicators of what West Greenwich can expect.

Empirical generalizations have been made concerning nonmetropolitan industrialization and its effects on local communities. In a clear majority of plant locations, the host community experiences population growth. Increase in the fiscal resource base of the local community often is outweighed by increased costs of providing services to the new industry and the community. New fiscal gains to the local government do occur. This usually is when no local subsidy was offered to the industry, or the plant work force is hired locally, or more commercial or industrial development takes place, or large proportions of the firm's work force live outside the community and commute to work (Summers et al 1976). It is a combination of these factors that will most likely result in net fiscal gains for the host community.

The transition to urbanization is likened to an ecological succession by sociologists. The existing population is viewed to be progressively replaced by another more complex, invading community until a stable climax stage is achieved (Ericksen 1954). This theory of urban ecology suggests the probability of a continuous and enduring battle between the proponents of tradition and the bearers of the new urban life styles. When the latter group reaches sufficient size it challenges the older, traditional group for leadership. In the threat to its leadership 
the older group sees that it not only faces the loss of community leadership and higher property taxes but also the defeat of their preferred way of life. Rural development studies have reported the occurrence of this phenomena.

In-migrants aften express more dissatisfaction with the local community services than long-term residents, particularly when the in-migrants are of higher skill and income levels than that of the host community residents (Lonsdale and Seyler 1979). Nonmetropolitan direction movers have been shown to exhibit high socioeconomic status with high incomes and high education levels when compared with nonmovers and metropolitan movers (DeJong and Sel1 1977). Conflicts may arise as this new group of in-migrants institue new values and modes of living which may contrast with the style of long-term residents.

Many local residents in these studies have expressed positive feelings about one or another aspect of industrial development; e.g., population growth, in-migrants, economic diversification, improved local shopping and work opportunity. While there are contrary feelings expressed, the majority of studies indicate that the scale weighs heavier in favor of optimism and satisfaction (Summers et al 1976).

With the nature of operations at Digital expected to be research, engineering and administrative work, the expected gains in aggregate income and unemployment rate may mask the net social benefit of the development to the total community. Attainment of the policy goals of rural development to provide income to maintain open space and to provide a sufficient level of income for rural population will depend upon the provision of local jobs as well as net fiscal gains to the community. The distribution of benefits, as well as their amount is an important issue when one is concerned with total community impact. 
What is done with the land resources of a particular land unit may benefit not only the holder of the unit on which the development takes place but also the potentialities of the land resources of nearby units. The complimentary benefit, i.e. positive externalities, can be such that the recipient unitl gains an advantage, the full worth of which can only be realized if the holder of the unit reaps its potential. If the gain in potential acts toward fulfillment of the owner's motive, as in when an owner is motivated to maximize capital gains, then the benefit is realized imediately. The actual returns will occur when the land is sold or developed.

Holders of land who pursue residential, agricultural, or silvicultural motives may incur only the advantage of a decreased tax burden due to net fiscal gains for the community at large. As mentioned above, this is not certain in the long run. The full worth of the advantage can be realized by re-planning the use of the land and participating in the land market.

\section{B. GENERAL OBSERVATIONS ABOUT LAND MARKETS}

A quantitative analysis of the effect of a major employer such as Digital moving into a town requires sophisticated information about the impact of the other factors that determine land supply and demand. Such information could be analyzed in an econometric model to forecast future states of the land market. This information which is developed from simplifications of economic reality could mislead rather than illuminate. Such "static" models are deficient in that their basic axiom of ceteris paribus "other things being equal" - can never apply to the world of human action, human innovation, human motivation, all of which can revise or upset previously established relationships and correlations that the economic theorist has come to take for granted. 
Because economics deals with open systems, precise predictions of future economic states are impossible. In an open system there are no real constants, no invariant relations, since everything is influenced, in no clearly determinate way, by everything else. What economic analysis does allow us to do is to forecast general consequences of current economic processes and policies, but with no exact time coefficient or exact measurement of those consequences attached to such forecasts. We can, therefore, estimate some of the qualitative effects of the Digital development on the land market.

Since Adam Smith, up to the present, economists have conceived market phenomena as an aspect of human relations that possesses an inherent order. Economic thoery and models are only possible if market participants are assumed to behave in an economically rational way. In other words, to make an economic analysis, economists assume that people-inthe-marketplace are more interested in improving their material condition than the pursuit of other interests.

Land market analysis examines the nature of land as a commodity. Its inherent problems arise from the supposition that land is a nonfungible commodity which is the subject of varied interests that predominate over interest in gains in material welfare. To many landowners, their land has become an extension of their own personality which carries with it a sense of posterity and inheritance. Many share the agrarian value that to be close to the 1 and is next to godliness. These people will be outside the scope of economics. Identification of this type of landowner has indeed been an objective of this study.

There are many landowners who will not be expected to participate in the land market unless they change their apparent motive. The owner whose motive is to obtain a steady flow of income from the use of his or her land 
resources as a farmer or lumberman may remain content as long as he or she satisfies one's own criteria of success. The holder of a land unit whose current reward is the subjective attraction of residential occupation may also not participate as long as he or she remains satisfied. The landowners who will primarily comprise the supply side of the land market are those who look upon their land resources as a financial investment. This person will act to maximize his income flow from his land and compare his returns or potential returns with the perceived performance of alternative investments open to him. The urban growth process changes the nature of the land market by converting non-participants through changes in motive and perceived rewards.

A recent study has shown that because of the opportunity for speculative profits from appreciation in land values, the character of both rural 1and and of its ownership begin to change more than twenty years before an area is actually urbanized (Brown et al 1981). Predevelopment landowners are a heterogenous group: rural farmers, sophisticated speculators, exurban commuters, smal1 investors, lumbermen, and development firms are found side by side. By understanding the nature of these owner groups and the factors that affect their landholding behavior, specific policies, guidelines and strategies which influence development potentials of the areas within town can be enacted.

1.) SUPPLY AND DEMAND

The aggregate of decisions by individual land market participants is called the land market. Land prices are apparently determined by market supply and demand. When discussing development of rural land, one should focus on land supply as the amount of land offered for sale at a particular time. Economists assume that the amount of the effective supply will increase in response to higher offering prices. This response can be plotted 
graphically with price asked constituting a vertical axis and land offered, a horizontal axis. A variety of factors will affect the slope of the curve including holding costs, market expectations, regulatory land use controls and characteristics of individual landowners.

The other side of the land market is land demand. It is a mirror image of effective land supply with the amount of land sought being inversely proportional to price. Land demand may be a function of population growth, migration, economic growth, costs of borrowing, travel costs, market expectations and the availability of attractive alternative investments. Effective supply and demand interact through the market to determine 1 and prices and land transferred. Effective land supply, land demand and the land market are all illustrated schematically in figures $1-3$ below.

FIG. 1. THE LAND MARKET-EFFECTIVE LAND SUPPLY
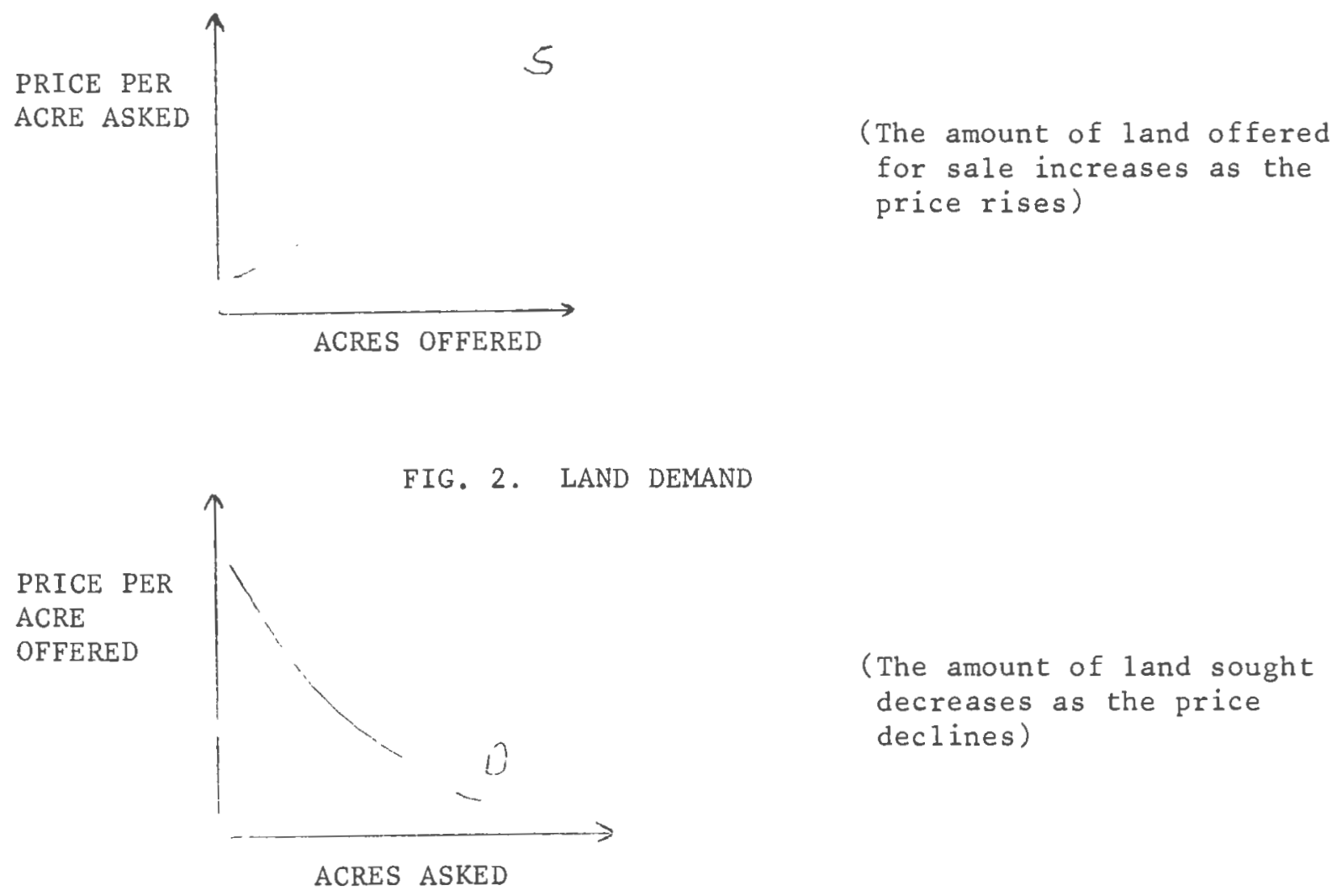
FIG. 3. LAND MARKET

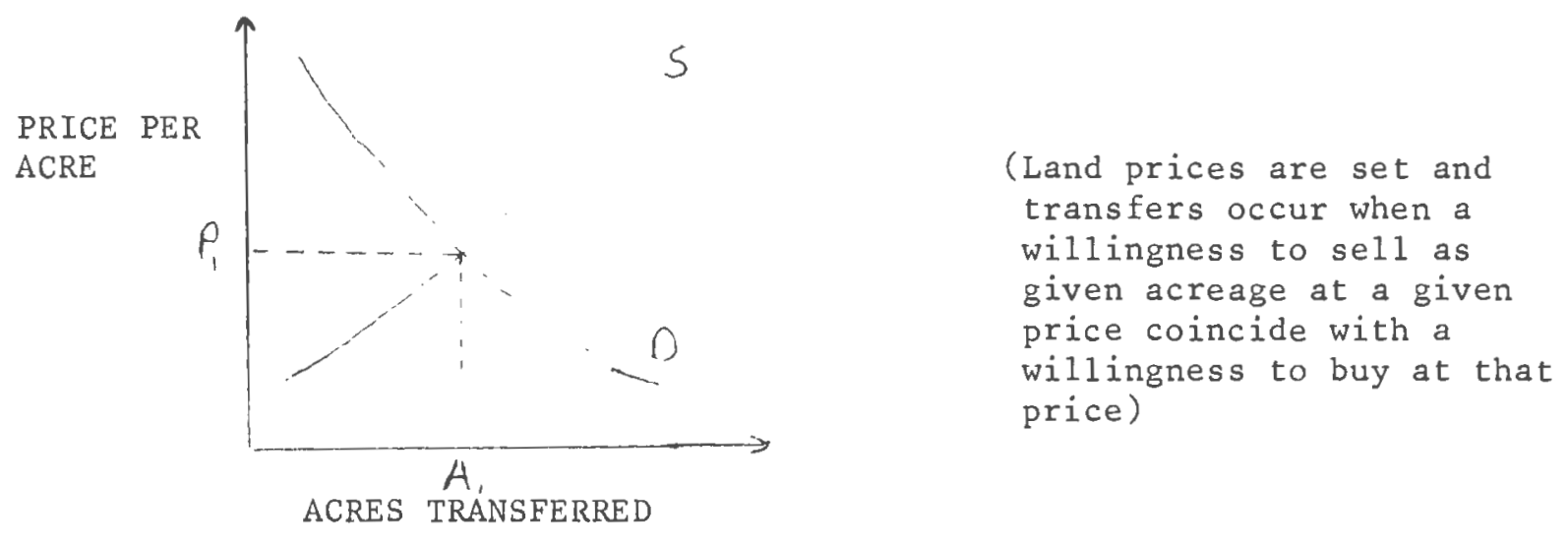

Observations by Lindeman (1976) and Schmid (1968) have suggested that investment activity itself can alter basic supply and demand forces operating in the market. Schmid presents evidence that there is considerably more expectation of future value increases built into the prices of fringe lots than that is actually realized in the history of established closer-in lots. Lindeman argues that the process of speculation increases land prices above what they would otherwise be. Recent economic trends do influence expectations about future land prices. Rising values stimulated by inflation or exogenous demand factors may touch off a speculative boom that bids prices upward in a self-sustaining spiral.

However, land markets can not sustain prices above the real economic returns of the highest use of the land. When speculative expectations are proven to be overly optimistic, the boom will collapse. Default or sale at a loss will occur but some investors may illogically refuse to sell at more reasonable prices. There may be a short-run restriction on market supply as this process takes some time. Eventually, the land will be sold at the reasonable market price.

Competitive market forces - the ability of developers to purchase land elsewhere - will tend to push land prices back toward equilibrium levels 
as long as the supply of developable land is not constrained. Higher prices will result in areas where development regulations restrict supply. These increases are the result of the perceived need to manage growth due to the consequences of growing demand.

2. THE EFFECT OF ECONOMIC DEVELOPMENT ON THIS LAND MARKET

The location of an employment center in town can cause more market participants to seek residential location in West Greenwich. According to trade-off theories of residential location, households will choose their locations in order to maximize their utility. In doing so, they will balance the costs and bother of commuting against the advantage of cheaper land and the satisfaction of more space for living (Alonso 1960). Choice of location will largely depend upon individual preferences for particular characteristics, services and amenities that different communities offer. Households will choose mostly between locations in different towns rather than a choice between locations in a single town (Losch 1954).

All we can say is that due to economic development, West Greenwich is likely to be the preferred choice of more households because of its special characteristics and, for some, its proximity to an individual's workplace. Figure 4 illustrates the effect of increasing demand causing the price and acres transferred to both go up.

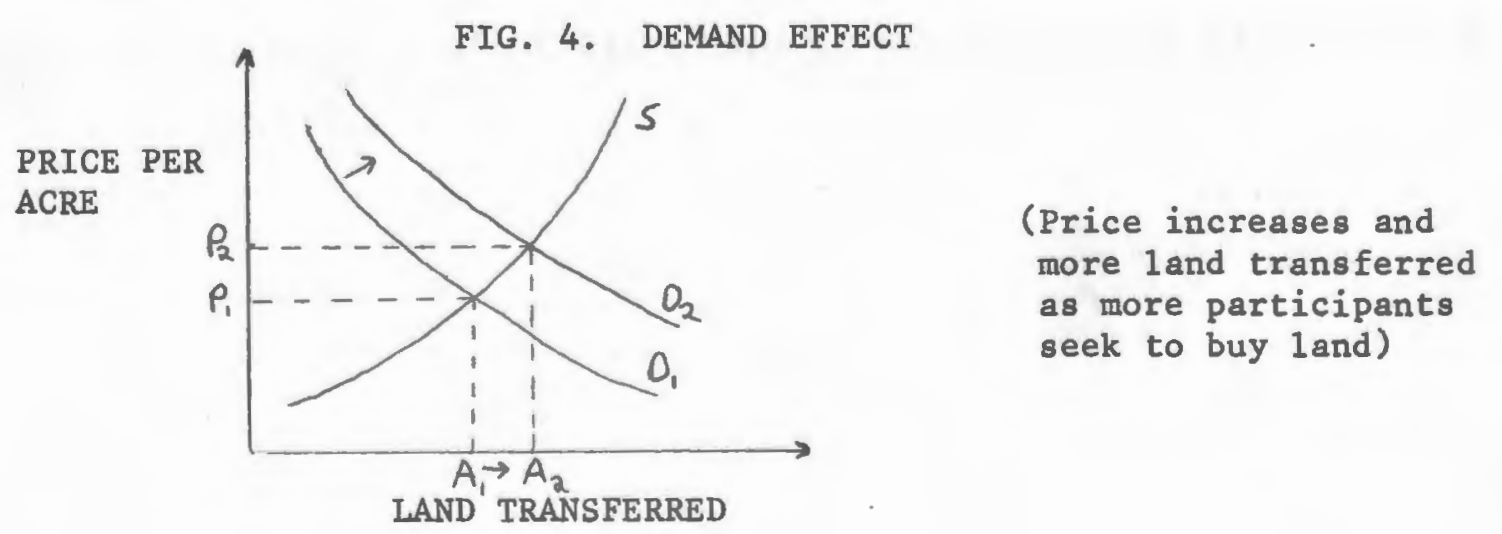


As residential development takes place in West Greenwich, more landowners may decide to offer land for sale. This may occur because of the higher price or as a reaction to the 1 and use changes in town. Figure 5 shows the effect of an increase in effective supply and the possible reduction in price corresponding to an increase in lands transferred. It is important to note that this simple model does not account for the effects of other factors which may negate or strengthen the effects of economic development.

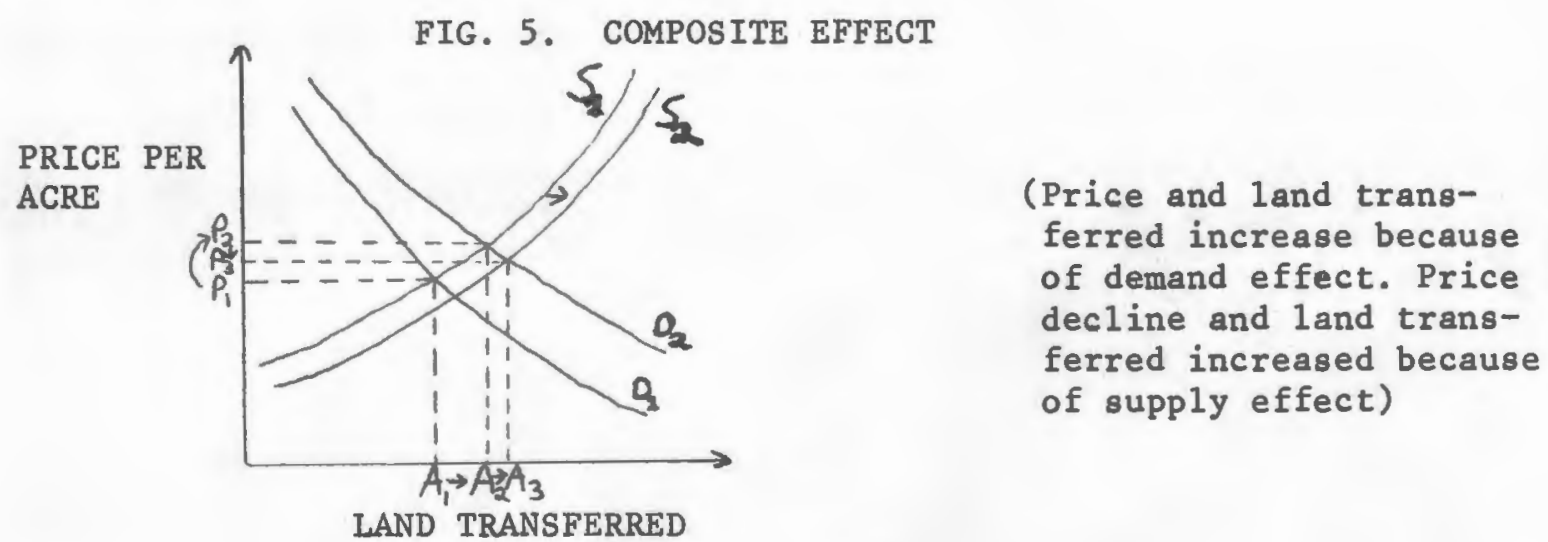

The foregoing discussion is potentially misleading in treating the local land market as a monolith. A simple supply and demand analysis has inherent limitations in being focused on only one frame in time. Moreover, the evidence suggests that life cycle factors of rural land turnover determine to a large extent when a particular parcel may be sold and which land is available for purchase at any given time (Brown et al 1981). The effective supply of land may therefore remain sluggish in response to changing demand, because supply is more responsive to personal factors than to economic factors. This is another reason why ownership studies are important.

C. INTERRELATIONSHIPS OF DETERMINANTS OF LAND USE

Economic factors are constantly interacting with the social determin- 
ants of land use. Both kinds of influence are completely interrelated so as to make differentiation and measurement of the seperate effects extremely difficult. While the location of workplaces tends to become a dominant influence affecting community patterns of development, social forces can run sympathetically with economic forces or they can run counter to them. To the sociologist, land use patterns have a direct relation to social processes and can be explained as the product of individual and group behavior in response to certain purely social as well as economic values.

Different explanations of land use have little practical meaning unless they are viewed in one interrelated matrix. As a guideline for applied analyses of land use, Chapin (1962) has provided a theoretical frame of reference based on the behavioral concept. According to this concept, land goes into use as a consequence of a myriad of individual and group actions. Motivated by values, ideals, and resultant articulated attitudes held by the various organized and unorganized segments of the population, these actions follow a defined behavioral sequence that culminates in land use changes. The results of behavior consciously calculated to influence land use is viewed as the set of rules and regulations known as land use controls.

Social, economic, and public control forces signify the interplay of factors that lend to various patterns of behavior that are the ultimate determinants of land use. Land use patterns evolve from actions derived from interacting values, not purely profit-making, not purely public interest, or culture-oriented values, but a combination of several values. Thus profit-making values result in a variety of actions in the land market which in the aggregate tend to produce purely economically motivated changes in the land use pattern. At the same time, certain livab- 
ility and culturally oriented values may have the effect of modifying these purely economic actions. As land use is changed and planned and unplanned consequences emerge, new behavior cycles are set in motion with feedback effects upon human values in the community.

The behavioral concept of land use advocates the need for recognizing the role that attitudes can play in land development. Sampling studies of attitudes may be expected to give perceptions into values, held by strategic action groups and the community at large. The need for ownership studies with balanced considerations has been established with the behavioral concept. It has defined the task of land use planners as one of seeking land use guidelines that take into account the physical practicalities of the land and identifies and interpolates from a changing base of the economic, and public interest values in order to project the kind of land development pattern that achieves a balance between all the relevant considerations.

Consistent with the behavioral concept is the decision analysis approach to spatial structure. The foregoing discussion clearly indicates that the manner in which the market and government interact in mediating location behavior is extremely complex. One way to follow this process is to focus on the decision as the critical point to the behavioral sequence in a location action.

of the many kinds of decisions by which space is adapted and put to use, two groups can be differentiated. One group involves what decision analysts call "priming decisions" in the sense that they are seen to trigger the other group, which involves "secondary decisions". The two together account for development as a whole. Examples of priming decisions are those involving public sector decisions to offer sites to industries and to build major highway interchanges and those involving 
private sector decisions on the location of industries with large employment. These decisions create the circumstances for secondary decisions. For example, capital improvements and adaptive land use planning may be decided upon in the public sector and development of subdivisions, lot purchasing or home building may be decided upon in the private sector.

The theoretical framework of this study uses the behavioral concept and decision analysis approach to establish probabilistic causality for the sequence of land use decisions. Major landowners are viewed as influenced by the set of strategic decisions by state and local government and by the Digital Equipment Corporation. Information has been gathered about the land and its owners to anticipate the degree of influence that landowners may experience for their own land use plans. In short, given the development by Digital in West Greenwich, this study is addressed to the question: How will landowners respond to the course of events and create the pattern of development? 
RELATED LITERATURE

The foundation of an ownership study rests upon knowledge gained from personal experience of the researcher and cognizance of the substantial literature on suburban land development (e.g. Brown et al 1981, Chapin 1962; Clawson 1962; Kaiser and Weiss 1970; Lindeman 1976;

Schmid 1968). Research concerned with ownership deals with a mixture of concepts that suggest a systematic approach to ownership behavior. Landowner theories explore relationships by inductive means of inferring truth from empirical observations. Theories of land ownership are still not adequate because there have not been enough studies to prove consistency in findings from one case to another.

Results may not be generalizable for most ownership studies because they are based on limited empirical data from a single metropolitan area (Finkler and Popper 1981; Kaiser et al 1968; Milgrim 1967; Sargent 1970; Strong 1966; Wolfe 1967). These studies are useful, however, in that they present methodologies that can be compared in developing an appropriate method for a particular study. The literature also suggests relevant hypotheses that can be tested for validity. A common feature of the hypotheses is the attempt to distinguish seller types from non-seller types. Undoubtedly, various factors will influence decisions to sell or develop one's land. Some of these are factors which will be somewhat unique to the owner. However, some of the factors may be more general to a group of people and can be used to recognize propensities to action or inaction. A model based on significant predictor variables was developed by a research team from the Center for Urban and Regional Studies (Kaiser et al 1968), to estimate the probability that a landowner will sell his land during a definite period in the future. 
Information from public records was collected concerning 400 parcels in two North Carolina cities. Statistical tests were applied to the data in order to develop a model which was able to classify 68 percent correctly as being sold or held over the ten year test period. Landowners were found to be more likely to sell if; he or she held the land less than ten years or longer than forty years; he or she does not live on the land; there is joint ownership; and there is considerable urban development nearby. This discriminant analysis model was considered for application in this study but was determined to be not appropriate for several reasons. The study clearly shows that the model needs to make unique calibrations according to the characteristics of a particular area. Despite its sophistication, the model made a substantial number of misclassifications and there is no assurance that a model calibrated on a past 10 year period will be successful for a future period.

Nevertheless, it illustrates that predictor variables can be found and that a planner can devise scoring schemes or indices that combine these variables. These scores can then be utilized as projections of tendencies in land market activity. These tendencies in turn may be mapped and used to anticipate problems and opportunities. It is important to note that the significance of ownership variables will to a large extent depend upon the nature of ownership and land in a particular community. ${ }^{4}$ A small study has been made of attitudes towards sale of land in eight townships of the Philadelphia metropolitan area (Strong 1966). In this study, two samples of 50 parcels each were taken to make comparisons of sellers and owners unwilling to sell. The non-sellers had held their land longer than the sellers. The beauty and openess of the area were considered prime factors inducing non-sellers to retain the land. Rising land values, and friends and family ties in the vicinity were the 
other major factors. Almost all of the owners holding for amenity or personal ties live on the property. In contrast, for many of those holding for future gain, the land is vacant. The important question raised by this study that remains unanswered is how extensive open space must be for resident land owners to continue planning to retain their property. Preservation of undeveloped rural land is encouraged by the State of Rhode Island in providing property tax relief in the form of use-value taxation. Many studies, however, have found that use-value assessment is not a major factor in land use decisions for the majority of participants (e.g. Barron and Thomson 1973, Brown et al 1981, Hansen and Schwartz 1975). It is considered ineffective in reducing sprawl because of the scattered nature of fringe area enrollments. A recent survey of more than 700 owners of undeveloped land outside six metropolitan areas in the United States and Canada indicates that tax burdens are not responsible for most land turnover (Brown et al 1981).

By providing a broad profile of rural landowners with an extensive survey, Brown's findings can be used as a comparison for studies like this one that are based on limited empirical data from one community. Since the few studies that have addressed the issues concerning the nature of the land market at the urban periphery have been limited in their scope, this broad information fills a void in the literature. The findings of this study will be described later as a comparison to the findings of the empirical analysis made here. 


\section{METHODOLOGY}

The study design involved the collection of data by various means. First, only parcels of at least ten acres were included since this size is assumed to have important implications as open space or developable 1and. An ownership map was drawn so that the physical properties of the land could be analyzed for each parcel by overlaying it on the set of transparent land use planning maps for the Town of West Greenwich.

The value of each land unit was obtained from the tax listing. Ownership information (e.g., form of ownership, year acquired, residency of owner, enrollment in the Farm, Forest and Open Space Property Tax Relief Program) was gathered from records of real estate transactions, mailing 1ist of property owners, tax assessor's list, and conversations with town officers. Finally, landowner attitudes and personal characteristics were assessed by way of a mailed landowner survey.

The environmental maps of West Greenwich are half the scale of the plat maps. Therefore, an ownership map was made by interpolating parcel boundaries from the plat maps onto a base map which was made by tracing the road network and the significant environmental features. Boundaries were carefully transposed, but can only be considered approximate.

The ownership map made it possible to calculate the percent of marginal lands for development potential variable. It also indicated the pattern of land use for the contiguous area surrounding each parcel. A judgement was then made on the potential for development of the contiguous area. The score for this "potential" was based on physiographic factors, ownership type, road conditions, street frontage and location. Although the score's determination is based on real factors, this index for potential development represents a qualitative judgement based on the above 5 factors. 
Land was evaluated for agricultural use as present farmland and potential crop production. Information collected for this study was used in conjunction with the Agricultural and Openlands Map of the Southern Rhode Island Conservation District in order to identify present and potential agricultural users. Each owner was then categorized with a value for agriculture.

Ten variables were established for all 177 landowners and placed in an ordinal scale. Associations of these variables were accomplished by using a set of assumptions which posit a tentative explanation of the relation between the variable and the propensity to develop a more intensive land use. The strength or weakness of the specific assumptions made are then determined by the variable's association with a series of Likert statements designed to reveal land use intentions; attitudes toward development and declared land use intentions; attitudes towards development and declared land use intentions which were revealed in the land owner survey are assumed as latent variables underlying or producing certain "potential" behavior.

The propensity to develop one's property to a more intensive land use is considered to be a function of the latent variables. Attitudes, as factors influencing behavior, may be one of many such factors, and not necessarily the most predominent. Other factors must also be taken into account to predict behavior. Some important factors cannot be known or foreseen. Therefore, this analysis must be regarded in that light. All known characteristics which may prove to be significant factors for the propensity to develop are evaluated by scalogram analysis to determine whether the variables can be discriminating in their operating characteristics on the underlying continuum of landowner types. 
Guttman scales are developed to rank each landowner according to statements and characteristics which influence propensity to develop and preferences for land use policies. To make estimates from the survey sample, another scale is constructed by summing up the relevant variables from the ten collected for all 177 landowners. Only variables which indicated a significant positive association with the Guttman scales are included in the general scale of propensity to develop. 6 To conduct this empirical analysis, a framework for the ten universal variable was constructed by the following suppositions:

1. Farm, Forest and Open Space Enrollment (FFOS) Enrollees have a lower probability of more intensive land use changes. They have declared their intention to retain rural use.

2. Residency of Owner -

a. An owner who lives on his land has the lowest or lower probability of creating a more intensive use.

b. The closer an owner lives to his 1and, the lower the probability that he would develop a more intensive use.

These assumptions are based on the hypothesis that psychological benefits such as "farming as a way of life," "love of the land," privacy, the land as a homestead, and status are included in a landowner's evaluation of his or her land use plans. If this is true, then someone who lives on the land would derive more benefits from the land than non-residents. He or she would also have higher transaction costs because of moving expense. With more benefits attributed to the resident owner along with higher transfer costs, he or she would be less likely to change toward a more intensive land use. Logic follows with the assumption that soil affinity is a function of spatial activity. The more removed 
physically an owner is from his land, the fewer psychological benefits he will enjoy. With fewer benefits and less affinity for his land, the distant owner may consider his or her land a commodity and seek financial gain by sale or development. This assumption is also supported by the findings reported by Kaiser (1968) and Strong (1966). Thus, the order of probability for more intensive land use from lowest to highest is expected to be; 1) resident owner; 2) owner - resident of West Greenwich, but not on land; 3) owner - resident of Rhode Island; 4) owner - resident of the United States; 5) owner - a foreign resident.

3. Form of Ownership -

The greater the influence of economic objectives in the organizational nature of ownership, the more probability of developing a more intensive use of land.

This assumption is based on the premise that institutional goals establish and set limits to motives and intentions. Therefore, corporate owners will pursue the primary objective of financial gain. Partnerships may act in a similar manner, but their objectives are not as obvious. The study team led by Kaiser (1968) found that the land was more likely to be sold if there was joint ownership. Non-profit institutions are assumed to use their land to satisfy the fulfillment of the particular meaning of the organization. Families act to satisfy a variety of needs and wants which are likely to complicate decisions to sell or develop family property. The order of likelihood for a more intensive land use change from lowest to highest are therefore: 1) family; 2) non-profit institutions; 3) partnerships; 4) corporations.

4. Length of Ownership -

The longer an owner holds his/her land, the lower the probability that he would intensify the land use. 
This proposition assumes that decisions are influenced by the ties of the past. As years of ownership go by, the ties become stronger and the owner perceives more benefit from preserving character of land. Land speculators and developers are more likely to be short term owners because they aim to convert land from rural to urban use when it becomes feasible in the marketplace. Strong (1966) has shown that non-sellers had held their land longer than the Sellers. Landowners were found by Kaiser (1968) to be more likely to sell if he or she held the land less than ten years or longer than forty years. [The ordinal scale selected is therefore; 1) greater than 20 years; 2) 10 to 20 years; 3) 5 to 9 years;

4) 2 to 4 years; 5) 1 year.]

5. Size of Parcel -

The size of a parcel has a direct relationship with the propensity to createmore intensive land use.

This supposition is based on the assumption that economies of scale and the nature of the land development industry are such that large tracts of land are preferred by developers. [The ordinal scale selected is: 1) 10 to 25 acres; 2) 26 to 50 acres; 3) 51 to 100 acres; 4) 101 to 200 acres; 5) greater than 200 acres.]

6. Percent of Margina1 Lands -

The higher the percentage of marginal lands for a particular land unit, the lower the probability that the land will become more intensively used.

[It is assumed that due to the environmental and economic constraints of marginal lands, the percentage of marginal lands will indicate a parcel's potnetial for more intensive uses. The ordinal scale selected is: 1) $81-100 \%$; 2) $61-80 \%$; 3) $41-60 \%$; 4) $21-40 \%$; 5) $0-20 \%$. 
7. Contiguous Land Use -

The more urbanized the surrounding area has become, the more likely that a rural land use will convert to a more intensive use.

The reasoning for this assumption is as follows. Property values increase as land is converted from rural to urban use. As urbanizatiion becomes contiguous with rural land use, there may be a decline in psychological benefits for the owner. Combined with the greater potential for financial gain, a landowner is more likely to sell or develop his 1and. Most ownership studies (Brown et.ald981, Kaiser et.al. 1968, Milgrim 1967, Sargent 1970, Strong 1966, Wolfe 1968) report a higher rate of land transactions when there is considerable urban development nearby. [Therefore, the ordering for the value of contiguous land use must range in scale from rural (1) to urban (5) according to the degree of urbanization.]

8. Potential for Development of Contiguous Lands If contiguous land becomes more developed over time, then chances are greater th the particular subject land unit will also become more intensively used.

The rationale is consistant with the logic given for the contiguous variable above. [The ordering is also the same.]

9. Agriculture Land in agricultural use is less likely than land that is not farmed to become more intensive in use.

This supposition is based on the assumption that the farmer is making a reasonable return from his operations. It also assumes that farmers receive psychological benefits based on agrarian values. [The ordinal scale selected is; 1) tilled farmland; 2) hay or pastureland; 
3) nursery; 4) openlands - acres that can be easily converted to farming; 5) all other lands].

10. Value -

The higher the assessed value of land is, the more likely it will be converted to a more intensive use.

It is assumed that the assessed value is at the present value. A high present value indicates that the land has a very good potential in the urban land market. The owner is therefore considered to have an interest in converting his use from rural to urban. [The ordinal scale selected is: 1) $\$ 0-\$ 3,000 ; 2) \$ 3,001-\$ 6,000 ; 3) \$ 6,001-\$ 10,000$; 4) $\$ 10,001-\$ 20,000$; 5) greater than $\$ 20,000$.

The preceding ten variables were determined for every one of the 177 landowners. Further information was sought through response to a landowner survey which was mailed out along with an introductory letter and self-addressed stamped envelope. The overall response rate for the owners survey was approximately 39 percent. Evidence of selective response by certain identifiable owner groups was not clear. As will be exhibited later, sample bias is probably not a serious problem. The information from 69 respondents established 41 more variables. From this sample, accurate information can be estimated for the study's population. In the mail-back surveys, owners of the 177 sampled parcels were asked to respond to a set of Likert statements, to relate their desires and expectations concerning the town's development potential, to reveal household characteristics (e.g. occupation, age, income) and land use characteristics (e.g. lease arrangements, agricultural and timber production), and to rank factors which help retain the land in its present use. A sample of the survey and introductory letter can be found in Appendix A. Many of the variables of the survey were included to provide important 
information which allows for better local and state policy-making decisions. These variables were considered neutral in their affect upon an owner's decision to intensify land use.

Certain questions were chosen to reveal the landowner's concerns for the process of community development. The proper role of government was also addressed by statements describing the appropriate mixture of land use control policies. Perception of community problems and preference for particular land use policies were coded to make their associations consistent and cumulative for measuring part of the same underlying continuum. Scores were given from one to five depending on how the answers could be indicative of certain types of landowners. Based on these responses, landowners were classified according to the continuum of preservationists, conservationists, moderate, promoter and developmentalist.

The independent variables from the survey which are chosen to examine their association with the dependent variables, landowner type by preference of public policies, are explained below. Those variables which indicate perceptions of community problems are listed first. Where the rationale for inference is not clear, an explanation is given. The number given for the variable indicates the order of placement on the survey form. Agreement with the following statements indicate a tendency to support less stringent regulations on development:

11. The lack of suitable moderate-income housing for rent is a problem in West Greenwich.

12. The lack of suitable moderate-income housing for sale is a problem in West Greenwich. The two variables above are considered as policy factors because it is believed that perception of housing problems in 
West Greenwich will lead to support of public policies designed to provide better circumstances for the housing industry. On the other hand, agreement with the statements below indicate a tendency to prefer implementation of land use controls that limit growth.

3. More intensive development of land will do serious damage to the attractiveness of the area.

8. Community facilities and service (food stores, retail shops, professional and trade services) are adequate for the needs of my household.

If an owner feels that local facilities and services are already adequate, then he or she will not foresee the advantages of community growth. Therefore, agreement with this variable indicates a tendency to favor policies that do not enhance growth.

There are five Likert statements on the survey form which suggest the acceptance or rejection of certain policy decisions. Three of these variables are not assumed to belong as part of the continuum of more restrictions vs. less restrictions or more growth, less growth, no growth. The preference for or against land use control policies other than what the statement specifically addresses can not be determined because the statements do not indicate a directional move along the continuum. These three statements are:

5. I am satisfied with the town's current land use control policies.

14. If society wants to preserve a rural environment, then the government should by the development rights directly from individual landowners.

16. The future development of West Greenwich should be centralized. 
The remaining two variables derived from the Likert statements provide information concerning land use policy issues and are specifically related to what the landowners think is the best type of approach for the town to have in designing land use policies. The issue is whether the town should devise more flexible regulations or more rigorous regulations; should the town accept growth and work out a cooperative relationship with the builders or should the town fight growth with more restrictions. These statements are:

10. I am in favor of more rigorous land use controls which put more restrictions on development.

18. Land use regulations should be more flexible in order to reduce housing costs.

The study presumes that a person's expressed desires for the population of the community in which he or she is a landowner will be a significant factor in determining which type of policies one will prefer. Therefore, the response to population preference was coded so that it could be classified on the five-part continuum.

All the relevant variables regarding policy issues of community development were evaluated to determine whether or not they meet the requirements of a Guttman scale. By means of item analysis, the best set of scalable statements was found to obtain a score for type of policy preference for each landowner. The policy type variables and the policy scale are examined for their relation to a landowner's personal land use policy.

The independent variables from the survey which are chosen to examine their association with the dependent variable, landowner type by personal land use policy, are explained below. Analysis of these variables is based on the assumption that people who strongly agree with 
the designated Likert statements are most likely to belong to the developer type of landowner and are expected to have the highest probability of changing to a more intensive land use.

The score for "expect to sell or develop within five years" has more validity than the other development indicators because its a specific statement with no conditional factors to consider. The other variables below are more complicated and require the respondent to analyze both the measuring of the factor and the effects of it. Since the responses are contingent on possible events with probability of their occurrence unknown, classification of landowners is susceptible to error due to problems of interpretation. The assumptions made are therefore rather weak but are necessary in order to provide a means for analysis. Agreement with the following statements are assumed to indicate a propensity to plan for sale or development:

2. Increases in property values may influence me to sell or develop my property to reap financial gain.

4. The burden of property tazes may pressure me into selling my property.

9. I expect to sell or develop my land within the next five years.

13. Lower interest rates will encourage me to sell or develop my 1and.

15. Retirement from my job will increase pressures on me to sell or develop my property.

17. Community capital improvements in my area (water, roads, sewers, etc.) will encourage me to sell or develop my land.

19. Current zoning and land use controls increase pressures on me to sell or develop my land. 
7. More intensive development of my neighbor's land may force me to sell or develop my land.

The expectation of new residential development on contiguous sites to the owner's land is considered a significant factor in the owner's land use plans. The possible decline in amenity may cause the landowner to change his or her plans and reap financial gain by sale or development. A landowner who expects his or her heirs to eventually gain possession of the land is also considered to have more interest in continuing the rural use of the land. The landowner is assumed to not only wish to bequeath possession of land but also the character form of the land which gives it special meaning to its owner and family.

Land which is owned by a person occupationally connected with real estate has a higher probability of sale or development. This assumption is stated with the premise that the 1andowner's occupational goal of transferring land as a commodity to enhance wealth predominates over other personal goals. Several other suppositions concerning occupation are also stated for analysis. Land owned by farmers and sawmill operators is less likely to be sold or developed than land owned by those not concerned with the productive use of the land for food and fiber. And, land owned by retired persons is more likely to be sold or developed than land owned by employed persons.

The assumption concerning farmers is based on the same reasoning given above for the variable number ten on agricultural use. Following the line of thought that farmers receive both monetary and non-monetary rewards from their use of the land which non-farmers cannot experience, owners who use their land productively for food and fiber are considered less likely to develop their land than those who do not use land for its natural products. The variables for percentages of agricultural and 
timber production have therefore been coded for testing of significance and possible inclusion in the calculus of landowner classification.

The supposition concerning retired persons is based on the reasoning that physical and financial limitations imposed by age may create a burden from maintenance and holding costs. As age increases, family status may change due either to death of a family member or simply because children marry and move away. Any of these changes could cause a change in an owner's plan for his land. Sale of land and possible development could occur.

An owner's level of income may also affect his plans. This study tests the hypothesis that land upon which the owner has a low level of income is more likely to be sold or developed, than land upon which the owner has a higher level of income. It is assumed that property taxes are a greater burden for lower income owners. The holding costs and the potential financial gain may prompt a sale. A person with a lower level of income is assumed to gain a greater marginal utility from sale than a person with a higher income. Therefore, the variable for income is also coded for further analysis.

The rank order scale of factors which help the respondent retain his or her land in its present use has been ordered from one to five. This enables statistical testing for each factor's association with other selected characteristics to indicate nature of individual's growth policy.

The text of scalability of the variables in the Guttman scale procedure is the degree to which the data fit the expectations of the researcher. Many factors may cause deviations from the expected pattern. The survey form may not be specific enough for some landowners to organize their responses in a consistent manner as measured from one 
variable to another. The survey could have been designed to have a unidemensional and cummulative function. Higher cutting points could have been used to improve the scale but would not have been able to distinquish those landowners who are not sure of how they will be influenced by economic growth and residential development.

Though the constructed scale barely meets the requirements of a Guttman scale, it is used to minimize skewness and categorize those landowners whose development tendencies are presently only marginal. A better Guttman scale should distinquish the obvious seller/developer type of landowner from others, but this information is already known. The scale devised here is used to obtain hidden information from the data so that a wider range of landowner types could be identified.

The entire study population of landowners were categorized by the construction of a potential land development index. The best available measure was to combine the values of the significant variables as determined by the scalogram analysis and correlation factors. The composite measure for each landowner was formed by summing up the values of FFos, residency of owner, type of owner, length of ownership, and agricultural use of land and then dividing by five. This simple estimator is admittedly crude, and not adquately precise for important predictions, but it is the best estimate available from the data.

Potential land development status indicate where patterns development are likely to be located. The scale devised for personal development policy is obviously the more accurate indicator of intentions. Where that scale developed from survey responses is not available, the estimate of potential land development status is used. The crude estimate is modified by other pertinent information that is known by the researcher. Errors are minimized by presenting information by area rather than by 
parcel. Besides concern for uncertainty, this technique provides for better protection of confidentiality.

An empirical data base has been generated through an extensive data collection process. It contains 51 indicators of the conceptual variables in which this study is interested. Hypotheses have been formulated concerning what pattern of inter-relationships should be found in the empirical indicators if the original ideas about landownership behavior were correct. The data was then analyzed using a variety of statistical techniques provided by the Statistical Package for the Social Sciences (SPSS) which is an integrated system of computer programs. Frequency distribution, correlation and Guttman scale analysis was used to determine whether the expected pattern of relationships could actually be discerned by the data. Finally, three variables which indicate future land development status was generated by mathematical and locial combinations of existing variables. 


\section{EMPERICAL ANALYSIS}

The empirical findings are presented in three parts: first, the frequency distributions are given for the study population and the relevant groups; second, the survey results are presented with the pertinent frequency distributions and correlation analysis which is used to indicate significant associations; and third, the scalogram analysis is discussed to explain calculation of potential land development status. OVERVIEW OF OWNERS AND LAND

The characteristics of landownership in West Greenwich are indicated by the array of observations for the eleven variables generated through the first phase of the data collection process described above. Land owned by the State of Rhode Island was not included in this analysis because its use of land is assumed to be already committed to the long range goals of their particular programs and therefore, not likely to change due to local economic development. A frequency distribution of the private landowner observations was constructed for the study population of 177 parcels to create a profile of landownership. The landowners were then separated into seven distinctive groups to reveal unique characteristcs. These severn groups are: 1. owners with more than 100 acres; 2 . owners who acquired parcels before $1961 ; 3$. owners who live on their land; 4. owners who participate in the Farm, Forest, and Open Space Program (FFOS); 5. owners in the form of partnerships or corporations; 6 . owners who responded to the survey; and 7 . owners who did not respond to the survey.

The ownership groups were chosen for comparative analysis for a variety of reasons. Landowner characteristcs of residents and long-term owners may have important political implications for land use policies. Information about participants in the Farm, Forest and Open Space Program 
may provide insight for evaluation of state policies for rural preservation. The control of rural land by partnerships and corporations is usually associated with conversion to urban uses. Survey respondents and non-respondents must be compared in order to estimate possible bias in the survey sample. Since large landowners have greater land use impacts on a community than owners of small parcels, it is important to understand their attributes for the development of effective land policies.

Landowners can be described either in terms of the fraction of land parcels they hold, or in terms of the total land area they own. As figure 6 demonstrates, the two ways of describing land often yield very different results. While 85 percent of the land parcels in the U.S. sample reported by Brown, Phillips, and Roberts (1981) and 88 percent of the land parcels in West Greenwich are smaller than 25 acres, these parcels represent a fraction of all land in their respective areas. In locations outside the metropolitan areas of Atlanta, Boston, Buffalo and Sacramento, the four percent of parcels larger than 100 acres account for more than 40 percent of the total fringe land (Brown et.al. 1981). In West Greenwich, 41 percent of the privately owned land area is accounted for by the 3 percent of parcels larger than 100 acres. Therefore, even though most of the land parcels in West Greenwich are relatively small, much of the total land area is held in quite large tracts.

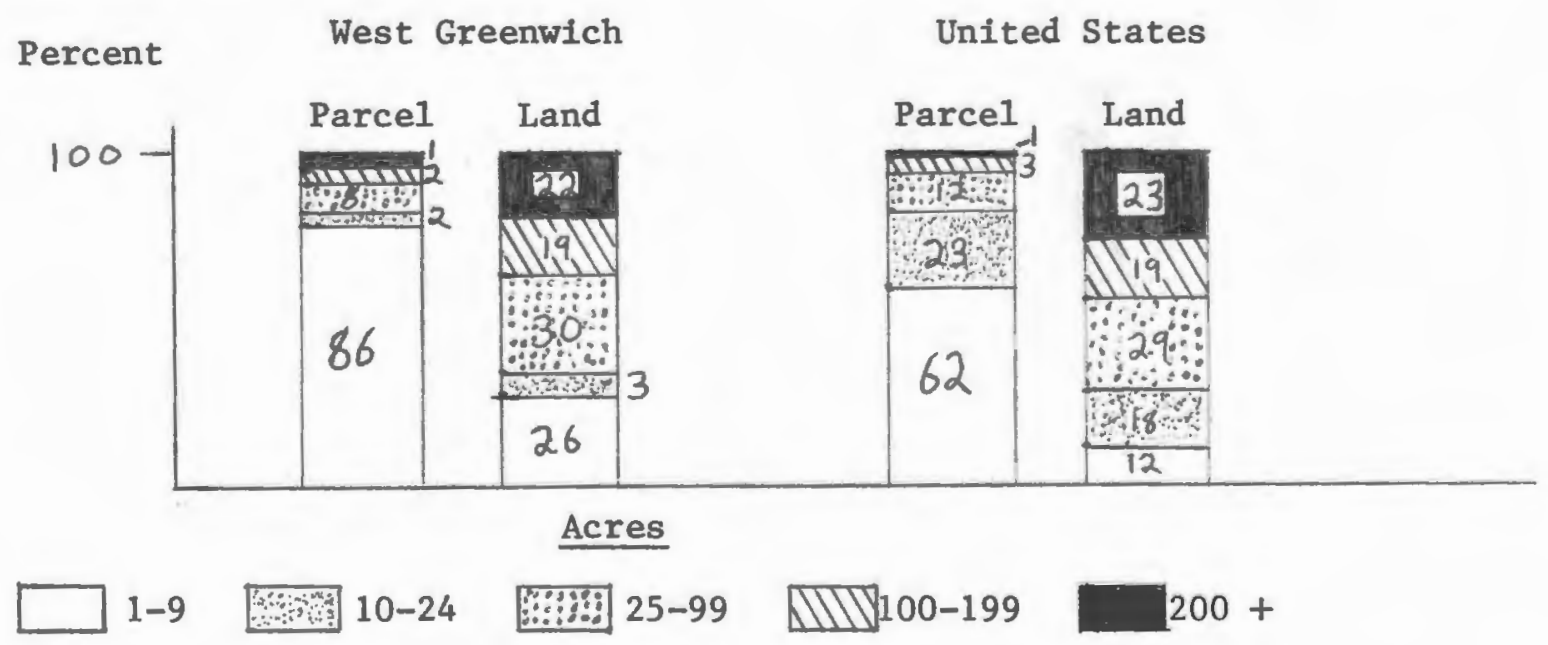

Figure 6: Size of Land Holding 


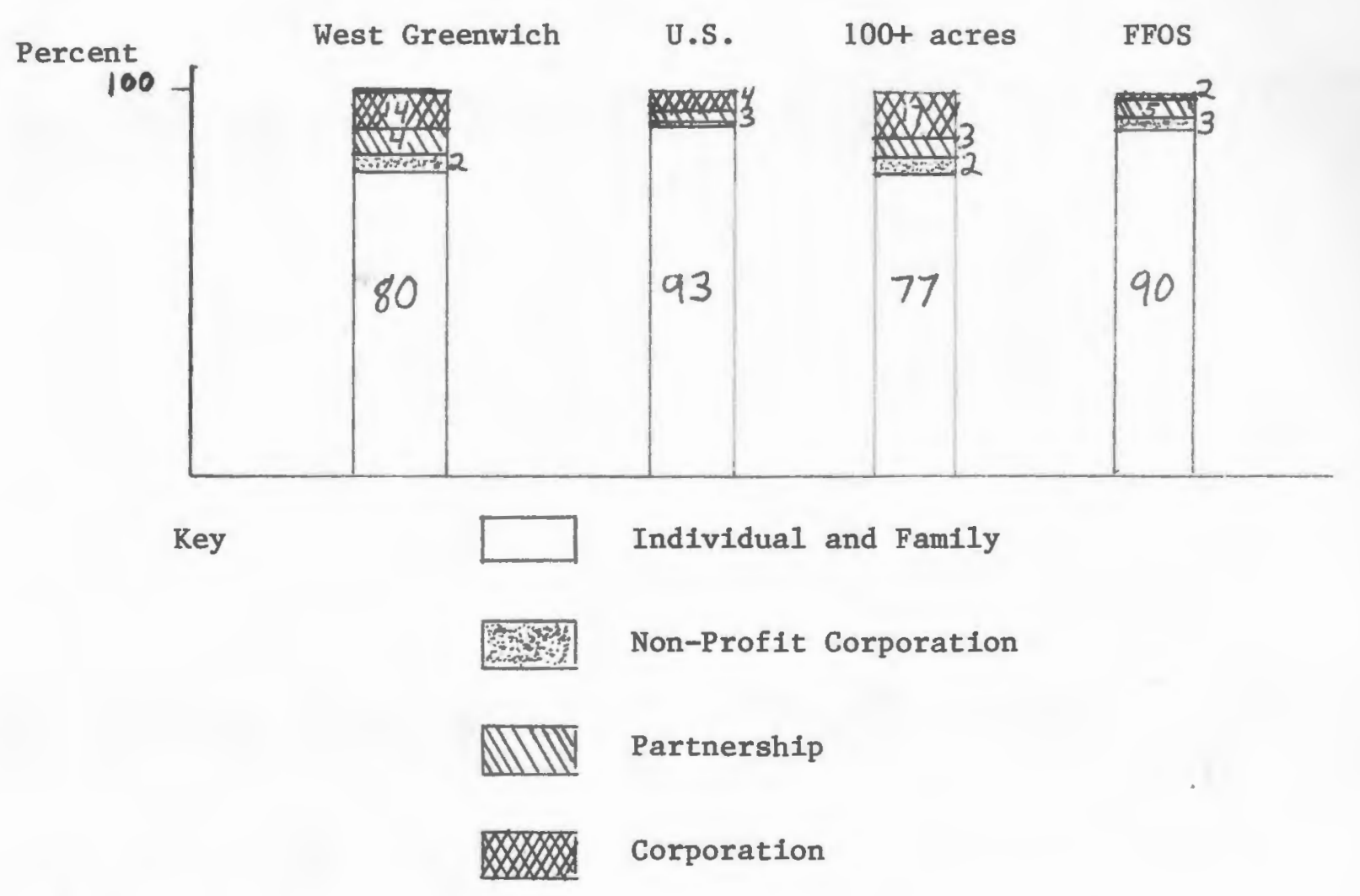

Figure 7: Form of Ownership

As figure 7 indicates, Individuals and families own the overwhelming proportion of 1and. They represent about 80 percent of the land parcels In West Greenwich and about 93 percent of the parcels in the U.S. urban fringe land sample. Partnerships and corporations hold about 18 percent of West Greenwich land parcels which is a much greater proportion than the 7 percent controlled by partnerships and corporations In the U.S. sample. When we look at the group of parcels which are greater than 100 acres, the control of large parcels by partnerships and corporations is slightly higher at 20 percent. Families and individuals make up a much greater fraction of participants in the FFOS Program with a rate of 90 percent.

The land market in West Greenwich has been relatively active. Figure 3 shows that 41 percent of West Greenwich landowners bought their land since 1971, and that 59 percent bought their land since 1961. 
The relative higher market activity is indicated by a comparison with the acquisitions of the U.S. sample. One-third of the U.S. land owners in the Brown study (1981) acquired their property since 1970, and nearly 60 percent bought their land since 1960.' Land transactions have been more than the average rate of U.S. transactions involving urban fringe land for the past ten years.

A singificant share of land, however, has been held for long periods. About 41 percent of West Greenwich landowners have held their land for more than twenty years. Fifty-eight percent of owners with land holdings larger than 100 acres have held their land since 1961. This indicates that parcels which changed ownership recently are smaller than average, reflecting the general tendency to subdivide large rural holdings in the face of urban growth.

Corporations and partnerships exhibit a more recent interest in West Greenwich. As figure 8 demonstrates, 61 percent of corporate owners have acquired their land since 1971. When compared with resident owners, who hold land almost entirely in family or individual ownership, corporate ownership shows a remarkable difference in length of ownership. This indicates that land in West Greenwich has become a better investment in recent years.

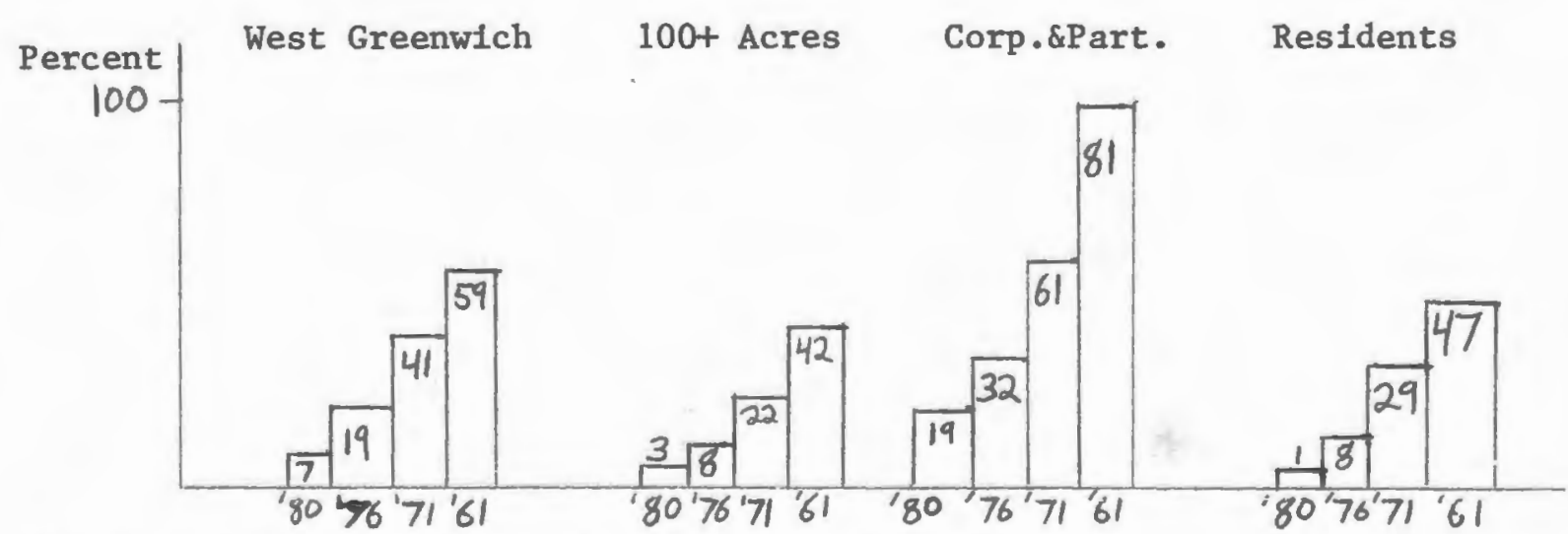

Figure 8: Percent of Parcels Acquired Since: 
About 56 percent of the land of West Greenwich is owned by people who live elsewhere. Seven percent of this group live on other land units in West Greenwich. Rhode Island residents in other communities comprise 45 percent of the study population of lanowners. The majority of these owners live in the nearby communities. There are only eight property owners from out-of-state which make up over four percent of the relevant 1and owners. No foreign residents own land in West Greenwich.

Nearly 44 percent of the land parcels are devoted to residential purposes. Agriculture has been determined to be a significant use by 20 percent of the total parcels and about 15 percent of the land area in West Greenwich according to the agricultural map. An estimate has been made from the landowner survey which indicates that 34 percent of land parcels have some degree of agricultural use. An estimate of 54 percent of the land parcels providing timber for use by owners has been made from the survey results. In addition to the recreational uses provided by the State parks, about 4 percent of the parcels are devoted to recreational activities. About one-fourth of the land parcels in west Greenwich is left idle and remains unused by its owners.

There are six parcels of 1 and in West Greenwich with more than three acres of land that are regularly tilled for crop production. Two parcels are used as nurseries. Twenty-seven land units have grasslands that are actively used for hay and pasture. The Soil Conservation Service has categorized eleven parcels as noncommitted idle lands that could readily be brought into agricultural production. ${ }^{7}$

West Greenwich has 57 landowners who are included in this study and are currently participating in the Farm, Forest and Open Space (FFOS) Program. They represent 32 percent of the land parcels and 30 percent of the land area in our study population. As mentioned above, 90 percent 
of the participants hold their land in the form of family or individual ownership. The program has a larger share of west Greenwich residents (65 percent), than the actual population of landowners (51 percent). Registration in the program comes from a greater proportion of more recent buyers of land than what holds true for the total study population. Fifty-three percent of the participants had acquired their land since 1971 which compares with 41 percent of the total. A significant difference in the development probability score given for the contiguous area was exhibited by the classification of 70 percent of the FFOS Program land unit's surrounding area as low potential which contrasts with 58 percent of low scores given to the entire study population. The 30 percent of agricultural land users in the program represent a greater proportion than what hold true for the total study population (20 percent). This is not surprising due to the nature of the program. Comparisons with the other variables yielded no significant differences.

From this analysis, a profile of the typical program participant can be made. Owners in the FFOS Program are most likely to be holding land in family or individual forms of ownership. They are more likely to be a local resident than most landowners. They purchased their land more recently than the average owner. The location of their land is very likely to be experiencing weak development pressures. The value of the land is likely to be less than the typical rural parcel. As expected, farmers make up a larger proportion of the owners in the program than they do overa11.

Table 1 lists the percent of frequency distribution for all ownership groups. A scan of the table demonstrates the difference in characteristics out1ined above. It is important to note that the survey sample shows no significant differences from the total population and the 
Table 1. Frequency Distribution of Owner and Property Characteristics* (percent)

\begin{tabular}{|c|c|c|c|c|c|c|c|}
\hline \multirow[t]{2}{*}{ Ownership Groups } & \multirow{2}{*}{\multicolumn{2}{|c|}{$\begin{array}{cc}\text { Survey } & \text { Response } \\
\text { Yes } & \text { No } \\
\end{array}$}} & \multicolumn{2}{|c|}{ FFOS } & \multicolumn{3}{|c|}{ Residence } \\
\hline & & & Yes & No & W.G & R.I. & U.S. \\
\hline Total & 39 & 61 & 32 & 68 & 51 & 45 & 4 \\
\hline Respondents & 100 & - & 37 & 63 & 52 & 45 & 3 \\
\hline Non-respondents & - & 100 & 30 & 70 & 50 & 45 & 5 \\
\hline W.G. residents & 40 & 60 & 43 & 57 & 100 & - & - \\
\hline Owners since 1961 & 36 & 64 & 22 & 78 & 64 & 27 & 8 \\
\hline FFOS & 42 & 58 & 100 & - & 65 & 33 & 2 \\
\hline Owners of $100+$ Acres & 38 & 62 & 28 & 72 & 50 & 47 & 3 \\
\hline Corporate Form & 26 & 74 & 13 & 87 & 16 & 81 & 3 \\
\hline
\end{tabular}

Form of Ownership

\begin{tabular}{|c|c|c|c|c|c|c|}
\hline \multirow[t]{2}{*}{ Ownership Groups } & \multicolumn{6}{|c|}{ Form of Ownership } \\
\hline & Family $\&$ & Individuals & $\begin{array}{r}\text { Non-profit } \\
\text { tion }\end{array}$ & Organiza- & Partnership & Corporation \\
\hline Total & & 80 & 3 & & 4 & 13 \\
\hline Respondents & & 83 & 5 & & 2 & 11 \\
\hline Non-respondents & & 78 & 5 & . & 2 & 15 \\
\hline W.G. residents & & 97 & - & & 1 & 1 \\
\hline Owners since 1961 & & 88 & 4 & & 1 & 7 \\
\hline FFOS & & 90 & 4 & & 5 & 2 \\
\hline Owners of $100+$ Acres & & 78 & 2 & & 3 & 17 \\
\hline Corporate Form & & - & - & & 23 & 77 \\
\hline
\end{tabular}

* sums may not add up to 100 due to independent rounding 
Table 1. Frequency Distribution* (percent) continued

\begin{tabular}{|c|c|c|c|c|c|c|c|c|}
\hline \multirow[t]{2}{*}{ Ownership Groups } & \multicolumn{3}{|c|}{ Time Period (years) } & \multicolumn{5}{|c|}{ Size (acres) } \\
\hline & $1-9$ & $10-20$ & $20+$ & $10-25$ & $26-50$ & $51-100$ & $101-200$ & $200+$ \\
\hline Total & 41 & 18 & 41 & 15 & 32 & 30 & 14 & 9 \\
\hline Respondents & 37 & 23 & 40 & 15 & 37 & 25 & 14 & 9 \\
\hline Non-respondents & 43 & 15 & 42 & 15 & 39 & 34 & 14 & 8 \\
\hline W.G. residents & 29 & 18 & 53 & 20 & 31 & 25 & 17 & 8 \\
\hline Owners since 1961 & - & - & 100 & 12 & 29 & 27 & 16 & 15 \\
\hline FFOS & 53 & 19 & 28 & 21 & 26 & 33 & 12 & 7 \\
\hline Owners of $100+$ Acres & 22 & 20 & 58 & - & - & - & 62 & 38 \\
\hline Corporate Form & 62 & 19 & 19 & 10 & 26 & 39 & 16 & 10 \\
\hline
\end{tabular}

\begin{tabular}{lcccccccc}
\hline Ownership Groups & \multicolumn{4}{c}{ Marginal Land } & \multicolumn{2}{c}{ Area Land Use Intensity } \\
\cline { 2 - 8 } & $0-20$ & $21-40$ & $41-60$ & $61-80$ & $81-100$ & Low & Moderate & High \\
\hline \multirow{2}{*}{ Total } & 7 & 20 & 36 & 25 & 11 & 29 & 69 & 2 \\
Respondents & 12 & 32 & 26 & 21 & 8 & 32 & 65 & 3 \\
Non-respondents & 11 & 20 & 42 & 20 & 7 & 27 & 71 & 2 \\
W.F. residents & 12 & 22 & 36 & 21 & 9 & 26 & 74 & - \\
Owners since 1961 & 10 & 27 & 34 & 14 & 10 & 30 & 67 & 3 \\
FFos & 9 & 21 & 35 & 28 & 7 & 35 & 65 & - \\
Owners of 100+ Acres & 3 & 22 & 40 & 28 & 8 & 52 & 48 & - \\
Corporate Form & 6 & 23 & 39 & 29 & 3 & 23 & 68 & 10 \\
\hline
\end{tabular}

* sums may not add up to 100 due to independent rounding 
Table 1. Frequency Distribution ${ }^{*}$ (percent) continued

\begin{tabular}{|c|c|c|c|c|c|c|c|c|c|}
\hline \multirow[t]{2}{*}{ Ownership Groups } & \multicolumn{3}{|c|}{ Area Development Potential } & \multicolumn{6}{|c|}{ Agricultural Use } \\
\hline & Low & Moderate & $\mathrm{High}$ & Crop & Hay & $\&$ pasture & Nursery & $\begin{array}{c}\text { Good } \\
\text { Potential }\end{array}$ & $\begin{array}{l}\text { Insig- } \\
\text { nificant }\end{array}$ \\
\hline Total & 4 & $\overline{93}$ & 3 & 3 & & 15 & 1 & 6 & 74 \\
\hline Respondents & 3 & 95 & 2 & 6 & & 12 & 3 & 2 & 77 \\
\hline Non-respondents & 4 & 91 & 5 & 2 & & 17 & - & 9 & 72 \\
\hline W.G. residents & - & 96 & 4 & 7 & & 30 & 1 & 6 & 56 \\
\hline Owners since 1961 & 3 & 94 & 3 & 6 & & 20 & - & 10 & 64 \\
\hline FFOS & 2 & 98 & - & 7 & & 19 & 3 & 4 & 67 \\
\hline Owners of $100+$ acres & 5 & 90 & 5 & 8 & & 12 & - & 15 & 65 \\
\hline Corporate Form & 3 & 87 & 10 & 3 & & 7 & - & 3 & 87 \\
\hline
\end{tabular}

\begin{tabular}{lrrrr}
\hline Ownership Group & Assessed Land Value $(\$)$ \\
\cline { 2 - 3 } & $0-3000$ & $3001-6000$ & $6001-10,000$ & $10,001-20,000$ \\
\hline
\end{tabular}

Total

Pespondents

Non-respondents

W.G. residents

Owners since 1961

FFOS

40

Cwners of $100+$ acres

Corporate Form

$\begin{array}{ll}40 & 31 \\ 41 & 36 \\ 40 & 28 \\ 57 & 22 \\ 47 & 26 \\ 57 & 29 \\ 8 & 25 \\ 6 & 32\end{array}$

\begin{tabular}{l}
11 \\
8 \\
12 \\
10 \\
10 \\
5 \\
18 \\
13 \\
\hline
\end{tabular}

\begin{tabular}{l}
7 \\
5 \\
8 \\
4 \\
4 \\
4 \\
23 \\
23 \\
\hline
\end{tabular}

* sums may not add up to 100 due to independent rounding 
non-response group. We can, therefore, assume that the responses of the survey can be used to accurately estimate the characteristics of the study population.

The Landowner Survey Results

The complete listing of responses by frequency is printed in the appendix. In this section: the attitudes concerning Digital Equipment Corporation's impacts on the community are described, the variety of intended land use policies of the landowners is outlined, the opinions for the appropriate land use policies of the town is explained, and the unique characteristics of six sub-groups of the survey sample are identified. The six groups were chosen for more in-depth analysis in order to determine accurate criteria for landowner classification. Selection and composition of the groups was suggested by the correlation analysis and the potential applications of the information. The six groups are ${ }^{8}$ : 1). owners who are residents of West Greenwich; 2). Owners who hold more than 100 acres of 1 and; 3). Owners who have held their 1 and for more than twenty years; 4). owners who participate in the FFOS Program; 5). owners who expect to sell or develop their land within the next five years; 6). owners who are not in favor of more rigorous land use controls which put more restrictions on development.

Land owners in West Greenwich hold a wide variety of occupations. About 30 percent of the landowners survey is comprised of responses from retired owners. Another substantial group of approximately 20 percent work as skilled tradesman. Management personnel make up close to 19 percent of the sample. Professional people such as architects, engineers, and administrators comprise about 13 percent of the landowner sample. People in banking and insurance own 5 percent of the land. The occupational class of farming, saw mill operators, realtors, and 
attorneys, each make up about 3 percent of the landowners in West Greenwich .

Close to 67 percent of the landowners are between the ages of 40 and 64. This relative percentage is about the same for al1 the landowner groups except for the long term owners who have 44 percent in the middle-aged group and 52 percent in the 65 and older age cohort. The total sample has 22 percent of its landowners over 65 . The older landowners comprise: 30 percent of the resident group; 39 percent of the owners with more than 100 acres; 14 percent of the FFos group; and 12 percent of the seller/developer group.

Only ten percent of the sample is comprised of owners between the ages of 25 and 39. The significant exception to the representation belongs to the seller/developer group and the FFOS group. These two groups have 18 percent of their landowners belonging within the age cohort 25 to 39 . There is only one landowner in the sample aged 18 to 24. While only about 35 percent of the residents are likely to be 40 years of age and older, this age group probably owns about 89 percent of the land in West Greenwich.

The approximate annual income of the households in this study is reported in an ordinal scale by range of income. The average income category is $\$ 30,000-\$ 39,000$. Twenty percent of the 1andowners report incomes less than $\$ 10,000$ and $\$ 19,000$. A total of 70 percent report incomes less than $\$ 39,000$.

The group of residents and owners with more than 100 acres have reported incomes close to the overall sample. Long term owners have the lowest reported income with 54 percent having income less than $\$ 19,000$ and 42 percent having income between $\$ 20,000$ and $\$ 39,000$. The FFOS group has a high level of reported income. Only 21 percent of this 
preferential taxed group reports income less than $\$ 19,000$. Most of the FFOS group, 46 percent, is in the middle income bracket of $\$ 20,000$ to $\$ 39,000$. The seller/developer group has the highest reported income with 59 percent of this landowner type having more than $\$ 40,000$ in annual income.

As Table 2 shows, survey respondents are optimistic concerning Digital Equipment Corporation's impacts on the community. While they overwhelmingly consider the addition of Digital as favorable to the community, its effects on their personal enjoyment is not expected to be positive by a majority of the owners. This phenomena indicates that the landowners expect net fiscal gains for the community, but do not perceive personal benefits. They do not equate some relief from their tax burden as enhancing personal enjoyment. They may consider the Digital development with caution because they consider it a precedent for further development which may cause damage. The majority feel that residential development will substantially increase due to the presence of Digital.

Table 3 indicates that a small majority of all the people surveyed agree that more intensive development of land will do serious damage to the attractiveness of the area. It is important to note that west Greenwich residents are the most concerned group about this possibility. Fears about serious damage is the most contributing factor towards the residents' significant difference from the total and other groups in regards to the Digital development. The cautious response to Digital and development in general is directly associated. The significant correlation between the response to "Digital will enhance my personal enjoyment" and the response to "more development will do damage" is -0.5550 which indicates that people who agree that more development will do damage will not consider the Digial development as an amenity for their 
Table 2. Landowner Response to Digital Development. ${ }^{1}$ (percent)

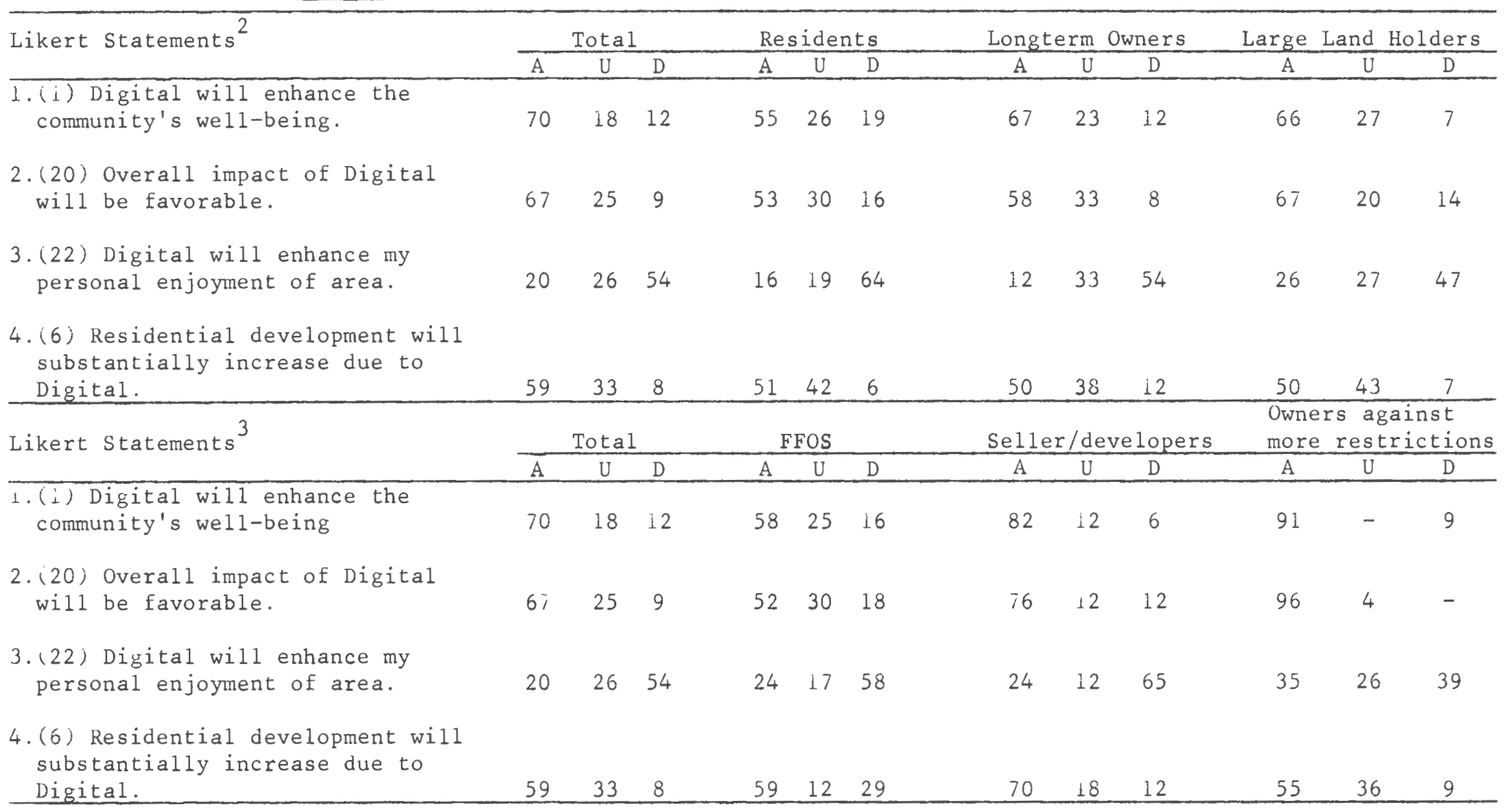

1. The scale of responses is collapsed from a range of five categories to a range of three categories in order to make the table easier to read.

2. Likert Statements are abbreviated. Number within parentheses corresponds to actual number on survey form.

3. Likert Statements and the total response are repeated for better comparison of all ownership groups. 
Table 3. Landowner Response to Community Development. ${ }^{1}$ (percent)

\begin{tabular}{|c|c|c|c|c|c|c|c|c|c|c|c|c|}
\hline \multirow[t]{2}{*}{ Likert Statements ${ }^{2}$} & \multicolumn{3}{|c|}{ Total } & \multicolumn{3}{|c|}{ Residents } & \multicolumn{2}{|c|}{ Longterm } & \multirow{2}{*}{$\frac{\text { owners }}{\mathrm{D}}$} & \multirow{2}{*}{$\frac{\text { Large }}{\mathrm{A}}$} & Land & \multirow{2}{*}{$\frac{\text { Holders }}{D}$} \\
\hline & $\overline{\mathrm{A}}$ & $\mathrm{U}$ & D & $\mathrm{A}$ & $\mathrm{U}$ & D & $\mathrm{A}$ & $\mathrm{U}$ & & & $\mathrm{U}$ & \\
\hline $\begin{array}{l}\text { (5) I am satisfied with current } \\
\text { land use policies. }\end{array}$ & 37 & 40 & 23 & 38 & 26 & 35 & 29 & 29 & 41 & 33 & 33 & 34 \\
\hline $\begin{array}{l}\text { 2. (8) Community facilities are } \\
\text { adequate. }\end{array}$ & 47 & 20 & 33 & 50 & 10 & 40 & 57 & 17 & 26 & 53 & 7 & 40 \\
\hline $\begin{array}{l}\text { 3. (11) The lack of suitable hous- } \\
\text { ing for rent is a problem. }\end{array}$ & 29 & 24 & 47 & 23 & 19 & 58 & 16 & 24 & 60 & 26 & 33 & 40 \\
\hline $\begin{array}{l}\text { 4. (12) The lack of suitable hous- } \\
\text { ing for sale is a problem. }\end{array}$ & 19 & 27 & 53 & 20 & 16 & 64 & 20 & 20 & 60 & 20 & 20 & 60 \\
\hline
\end{tabular}

5. (3) More development will do

serious damage.

\begin{tabular}{|c|c|c|c|c|c|c|c|c|c|c|c|c|}
\hline serious damage. & 52 & 14 & 33 & 74 & 3 & 23 & 62 & 23 & 15 & 73 & 7 & 20 \\
\hline \multirow[t]{2}{*}{ Likert Statements ${ }^{3}$} & \multicolumn{3}{|c|}{ Total } & \multicolumn{3}{|c|}{ FFOS } & Se11 & $/ \mathrm{de}$ & lopers & \multicolumn{3}{|c|}{$\begin{array}{l}\text { Owners against } \\
\text { more restrictions }\end{array}$} \\
\hline & $\bar{A}$ & $\mathrm{U}$ & D & $\mathrm{A}$ & $\vec{U}$ & D & $\mathrm{A}$ & $\mathrm{U}$ & $\mathrm{D}$ & $\mathrm{A}$ & $\mathrm{U}$ & $\mathrm{D}$ \\
\hline $\begin{array}{l}\text { 1.(5) I am satisfied with current } \\
\text { land use policies. }\end{array}$ & 37 & 40 & 23 & 42 & 42 & 17 & 36 & 53 & 12 & 36 & 41 & 23 \\
\hline $\begin{array}{l}\text { 2. ( } 8 \text { ) Community facilities are } \\
\text { adequate. }\end{array}$ & 47 & 20 & 33 & 55 & 17 & 29 & 35 & 35 & 30 & 35 & 23 & 42 \\
\hline $\begin{array}{l}\text { 3. (ii) The lack of suitable hous- } \\
\text { ing for rent is a problem. }\end{array}$ & 29 & 24 & 47 & 20 & 25 & 54 & 54 & 12 & 26 & 35 & 26 & 39 \\
\hline $\begin{array}{l}\text { 4. (12) The lack of suitable hous- } \\
\text { ing for sale is a problem. }\end{array}$ & 19 & 27 & 53 & 20 & 25 & 55 & 30 & 18 & 43 & 22 & 22 & 57 \\
\hline
\end{tabular}

5. (3) More development will do serious damage.

$\begin{array}{llllll}52 & 14 & 33 & 58 & 17 & 25\end{array}$

$\begin{array}{lll}36 & 12 \quad 53\end{array}$

$\begin{array}{lll}36 & 9 & 55\end{array}$

i. The scale of responses is collapsed from a range of five categories to a range of three categories in order to make the table easier to read.

2. Likert Statements are abbreviated. Number within parentheses corresponds to actual number on survey form.

3. Likert statements and the total response are repeated for better comparison of all ownership groups. 
personal enjoyment of the area.

The concerns for the problems of development is positively associated with the majority opinion that the lack of suitable moderateincome housing for rent or sale is not a problem. Residents and long term owners have the largest majorities of people in accordance with this view which indiates again that they have less interest in development and more apprehension in residential growth. Table 3 shows that the seller/developer group deviate substantially from the other groups in their assessment of community problems and development activities.

There are some benefits of residential development to existing residents. Growth would enable West Greenwich to support more community facilities and services such as food stores, commercial establishments, and special professional and trade services. Most landowners, however, think that these economic amenities are already adequate. The range of response is about the same for each group except for a notable difference from the seller/developer group and the group against more restrictions on development. These two groups are the only ones with a majority stating that the community facilities are not adequate.

Though most people are undecided about the quality of the Town's current land use control policies, Table 4 shows that they are decisive in choosing specific guidelines for policies. Landowners lend much more support to regulations that put restrictions on development than on regulations which are flexible for development. The low proportion of agreement with the need for more flexible regulations reflects the concern for possible damage that development could cause and lack of trust for the building industry. Though concern about potential damage from more intensive development has been expressed by a substantial majority, policies to preserve the rural environment by more rigorous land use controls 
Table 4. Landowner Response to Policy Choices. ${ }^{1}$ (percent)

\begin{tabular}{|c|c|c|c|c|c|c|c|c|c|c|c|c|}
\hline \multirow[t]{2}{*}{ Likert Statements ${ }^{2}$} & \multicolumn{3}{|c|}{ Total } & \multicolumn{3}{|c|}{ Residents } & \multicolumn{3}{|c|}{ Longterm owners } & \multicolumn{3}{|c|}{ Large Land Holders } \\
\hline & A & $\mathrm{U}$ & D & A & $\mathrm{U}$ & D & A & $\mathrm{U}$ & D & A & $\mathrm{U}$ & $\mathrm{D}$ \\
\hline $\begin{array}{l}\text { 1. (10) I am in favor of more re- } \\
\text { strictions on development. }\end{array}$ & 43 & 20 & 36 & 48 & 19 & 32 & 42 & 31 & 27 & 34 & 20 & 47 \\
\hline $\begin{array}{l}\text { 2.(16) Future development should } \\
\text { be centralized. }\end{array}$ & 50 & 24 & 26 & 49 & 29 & 21 & 68 & 16 & 16 & 47 & 20 & 33 \\
\hline $\begin{array}{l}\text { 3. (18) Land use regulations } \\
\text { should be more flexible. }\end{array}$ & 28 & 19 & 54 & 23 & 23 & 55 & 27 & 27 & 46 & 26 & 27 & 47 \\
\hline $\begin{array}{l}\text { 4. (14) Government should buy } \\
\text { development rights. }\end{array}$ & 35 & 12 & 52 & 29 & 16 & 55 & 35 & 23 & 42 & 40 & 20 & 40 \\
\hline \multirow[t]{2}{*}{ Likert Statements ${ }^{3}$} & \multicolumn{3}{|c|}{ Total } & \multicolumn{3}{|c|}{ FFOS } & \multicolumn{3}{|c|}{ Sel1er/developers } & \multicolumn{3}{|c|}{$\begin{array}{l}\text { Owners against } \\
\text { more restrictions }\end{array}$} \\
\hline & $\mathrm{A}$ & $\mathrm{U}$ & $\mathrm{D}$ & $\mathrm{A}$ & $\mathrm{U}$ & $\mathrm{D}$ & $\bar{A}$ & $\mathrm{U}$ & D & $\mathrm{A}$ & $\mathrm{U}$ & $\mathrm{D}$ \\
\hline $\begin{array}{l}\text { 1. (10) I am in favor of more re- } \\
\text { strictions on development. }\end{array}$ & 43 & 20 & 36 & 66 & 17 & 16 & 24 & 29 & 47 & - & - & 100 \\
\hline $\begin{array}{l}\text { 2. (16) Future development should } \\
\text { be centralized. }\end{array}$ & 50 & 24 & 26 & 55 & 21 & 24 & 30 & 41 & 29 & 39 & 26 & 34 \\
\hline $\begin{array}{l}\text { 3. (18) Land use regulations } \\
\text { should be more flexible. }\end{array}$ & 28 & 19 & 54 & i2 & 25 & 62 & 24 & 24 & 52 & 59 & 9 & 31 \\
\hline $\begin{array}{l}\text { 4. (14) Government should buy } \\
\text { development rights. }\end{array}$ & 35 & 12 & 52 & 24 & 8 & 67 & 47 & - & 53 & 48 & - & 52 \\
\hline
\end{tabular}

1. The scale of responses is collapsed from a range of five categories to a range of three categories in order to make the table easier to read.

2. Likert Statements are abbreviated. Number within parentheses corresponds to actual number of survey form.

3. Likert Statements and the total response are repeated for better comparison of all ownership groups. 
received only moderate support. It is important to note that FFos participants are unique in their significant approval of more restrictions and related disapproval of flexible regulations. Residents also show a strong preference for strict regulations and little sympathy with the need for flexible regulations. A surprising finding of the response from the owners who expect to sell or develop within the next five years reveals a problem in analyzing that group. Only 24 percent of the seller/developer group perceive a need for more flexible regulations. This is certainly not what was expected from the hypothesis made here and from the concerns within the building industry and planning profession. The inconsistency may be due to the composition of the group and a weakness in the survey form. The seller/ developer group includes both the typical land developers who convert land from rural to urban uses and the investor who transfers his or her land with the use remaining unchanged. The group also includes landowners of wood lots who plan to develop their land for personal residential occupation. The motives of this group are not homogenuous, and therefore, the response cannot bee considered indicative of the development industry's recommendations for improving land use controls.

Government purchase of development rights directly from individual landowners is not approved of by the majority of landowners. Table 4 shows, however, that three of the ownership groups are ambivalent about this policy. The important ownership group, large land holders, which would be the primary target of this policy has an equal number for and against it. The seller/developer group and the group of owners against more restrictions have only a slim majority against this policy. All other landowner groups are definitely against the purchase of development rights. 
Policies to direct growth towards a central area may gain support. Fifty percent of the sample are in agreement that the future development of West Greenwich should be centralized. All of the sample groups indicate support for the policy except for the seller/developer group which has an equal proportion of owners who are for and against centralization. Long-term owners have an overwhelming majority of 68 percent in favor.

The desires for population are considerably lower than the expectations. Most landowners, 57 percent, do want to see the population in 1990 to be moderately larger than it is today. Only 3 percent want it greatly enlarged; 24 percent want it to remain the same; and 6 percent want to see a decline. Residents and owners with large holdings have a high proportion, 42 percent and 40 percent respectively, who would like to see the population remain stable or decline. There are no residents who would like to see the town's population become greatly enlarged. The responses of the population expectations of these groups, however, show that they do not expect to get what they want.

The population of West Greenwich in 1990 is expected to be moderately larger than it is today by 72 percent of the sample. Nobody expects the population to be about the same as it is today nor less than it is today. Fifteen percent expect the population to be greatly enlarged from what it is today. The expectations run about the same for all groups except the FFOS sample. This group has 25 percent of its individuals expecting a very high rate of population growth.

Table 5 lists the significant correlation coefficients of the total response to policy issues. All of the variables were tested for collinearity of the propensity to sell/develop by coding all variables to correspond with the expected placement along the preservationist - developmentalist continuum. This was done so that a cumulative scale could be constructed. 
Table 5. Significant Correlation Coefficients of Total Response to Policy Issues Concerning Community Development*

\begin{tabular}{|c|c|c|c|c|c|c|c|c|}
\hline Factors & $\begin{array}{l}\text { Development } \\
\text { will do } \\
\text { damage }\end{array}$ & $\begin{array}{l}\text { Community } \\
\text { facilities } \\
\text { are adequate }\end{array}$ & $\begin{array}{l}\text { Favor of } \\
\text { more restric- } \\
\text { tions }\end{array}$ & $\begin{array}{l}\text { Housing for } \\
\text { rent is a } \\
\text { problem }\end{array}$ & $\begin{array}{l}\text { Housing for } \\
\text { sale is a } \\
\text { problem }\end{array}$ & $\begin{array}{l}\text { Regs. should } \\
\text { be more } \\
\text { flexible }\end{array}$ & $\begin{array}{l}\text { Preference } \\
\text { for size of } \\
\text { population }\end{array}$ & $\begin{array}{l}\text { Bi-serial } \\
\text { corr scale- } \\
\text { item }\end{array}$ \\
\hline $\begin{array}{l}\text { Development } \\
\text { will do } \\
\text { damage. }\end{array}$ & - & 0.2234 & 0.4030 & 0.2606 & 0.3099 & n.s. & 0.5043 & 0.4510 \\
\hline $\begin{array}{l}\text { Community } \\
\text { facilities } \\
\text { are adequate. }\end{array}$ & 0.2234 & - & $0.255 \%$ & 0.2978 & 0.3561 & 0.2579 & 0.2395 & 0.3865 \\
\hline $\begin{array}{l}\text { Favor of more } \\
\text { restrictions } \\
\text { on development. }\end{array}$ & 0.4030 & 0.2557 & - & $\mathrm{n} . \mathrm{s}$. & n.s. & 0.4648 & 0.3326 & 0.3537 \\
\hline $\begin{array}{l}\text { Housing for } \\
\text { rent is a } \\
\text { problem. }\end{array}$ & 0.2606 & 0.2978 & $\mathrm{n} \cdot \mathrm{s}$. & - & 0.7225 & 0.4148 & 0.3519 & 0.4497 \\
\hline $\begin{array}{l}\text { Housing for } \\
\text { sale is a } \\
\text { problem. }\end{array}$ & 0.3099 & 0.3561 & n.s. & 0.7225 & - & 0.4048 & 0.2633 & $0.583 \mathrm{I}$ \\
\hline $\begin{array}{l}\text { Regulations } \\
\text { should be more } \\
\text { flexible. }\end{array}$ & n.s. & 0.2579 & 0.4648 & 0.4148 & 0.4048 & - & 0.3301 & 0.4324 \\
\hline $\begin{array}{l}\text { Preference for } \\
\text { size of popu- } \\
\text { lation. }\end{array}$ & 0.5043 & 0.2395 & 0.3326 & 0.3519 & 0.2633 & 0.3301 & - & 0.4633 \\
\hline
\end{tabular}

n.s. - not significant

* - Level of significance for students $t$ set at five percent 
The bi-serial correlation scale-item enables the reader to easily spot the degree of positive association that each variable has in relation to the other variables in the scale. Policy variables that were not included in the scale, i.e. "satisfaction with current land use policies," "government should purchase development rights," and "development should be centralized," have neutral correlation coefficients. It is important to note that the correlation coefficients for "housing for rent is a problem," "housing for sale is a problem" and "regulations should be more flexible" would all be negative if they were not recoded for scale construction.

People who expect more development to be damaging to the attractiveness of the area tend to favor more restrictions on development and would like to see the population of West Greenwich to remain the same or become only moderately larger. Landowners who sympathize with the need for more flexible regulations generally do not favor more restrictions on development and consider housing for sale and for rent a problem in West Greenwich. The highest correlation coefficient is between the two variables relating to the problem of housing. If a landowner considers housing for sale to be a problem, then he or she is very likely to also consider housing for rent a problem.

Though a11 of the variables in this group are positively related to the scale, the group of items do not constitute a valid scale. Its coefficient of scalability was figured to be equal to 0.3673 . Various sets of variables were then combined to determine the best set of scalable statements. The variables: "development will do damage," "favor of more restrictions", "regulations should be more flexible," and "preference for size of population" were considered to have the best discriminating characteristics by intuition and were also shown to have the highest coefficient of scalability which is 0.5455 . These four variables were used to develop a score for each respondent to the landowner survey based on 
type of policy preferences. Discussion of the scales' association with other factors will follow the development of another relevant scale based on personal land use policy.

Table 6 lists the frequency of responses to the stated factors which could encourage sale or development of land. Every factor has a corresponding majority of owners who deny the possibility of influence. A majority of landowners do not anticipate the sale or development of their land within five years. A large majority do not expect retirement to make them more willing to sell or develop. A vast majority of residents, long-term owners and large land holders expect to own their land for the rest of their lives.

A feeling of posterity is associated with land ownership for most of the survey sample as is shown by Table 6 . Only one person out of fifteen in the group of owners with more than 100 acres does not think that his or her land will be passed along to the next generation in the family. A sense of history appears to be very important to the Town of West Greenwich. There are many landowners who are descendants of the original settlers. Not only does the land have significant personal meaning for the owner, but it also carries with it a sense of family identity that may be a strong factor in preserving its rural land use character.

A notable difference in reaction to more intensive development of neighbor's land is recorded by long-term owners. While all the other groups had a clear majority of owners who did not think that development of neighbor's land would force them to sell/develop their 1and, longterm owners had an equal number of those that thought they would be affected as those that thought the o.posite. This could be an important factor in the town's pattern of growth, especially since 25 percent of the landowners 
Table 6. Landowner Response to the Influence of Development Factors on Current Land Use. 1

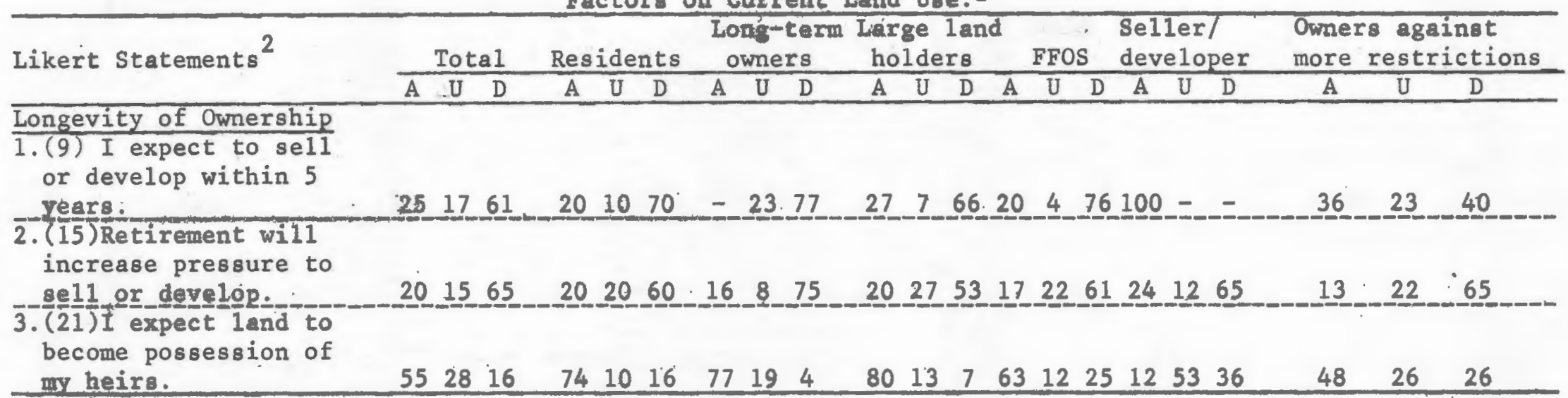

my heirs.

Financial Considerations

values may influence

$5 .(4)$ Burden of property

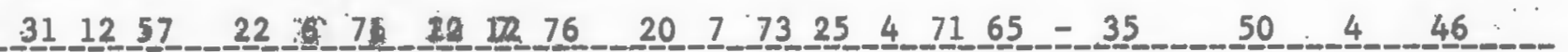

5. (4) Burden of property

$38.21 \quad 41-2929.42 \quad 32 \quad 20 \quad 48 \quad 33 \quad 27 \quad 40 \quad 38 \quad 25 \quad 38 \quad 42 \quad 12 \quad 46 \quad 34 \quad 22 \quad 44$

6. (13) Lower interest

rates will encourage

sale.

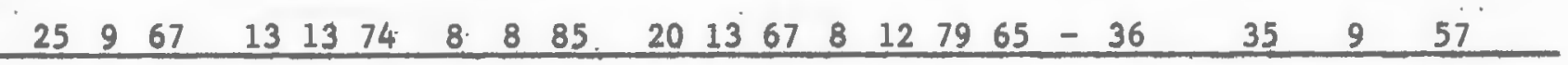

Community Fecture

7. (17)Capital improve-

ments in area will en-

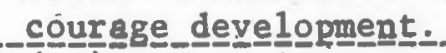

$35 \quad 20 \quad 45 \quad 23 \quad 23 \quad 55 \quad 25 \quad 25 \quad 50 \quad 27 \quad 20 \quad 53 \quad 20 \quad 25 \quad 54 \quad 42 \quad 12 \quad 47 \quad 41$

8. (19) Current land use

policies increase

pressure to sell/de-

velop

$\begin{array}{lllllllllllllllllllll}11 & 12 & 76 & 7 & 7 & 86 & 4 & 12 & 83 & 13 & 13 & 73 & 12 & 8 & 79 & 18 & 12 & 70 & 22 & 14 & 63\end{array}$

Contiguous Uses

9.(7) Development of..

neighbor's land may

force sale or develop-

ment.

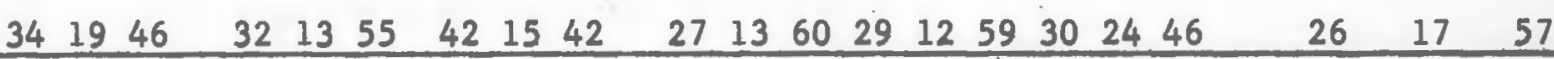

1. The scale of responses is collapsed from a range of five categories to a range of three categories in order to make the table easier to read.

2. Likert Statements are abbreviated. Number within parentheses corresponds to actual number of survey form. 
expect new residential development on neighboring property within five years. If the character of the area is not maintained, then one development could lead to another with the familiar result being suburban sprawl. An exceptional coincidence indicates that landowners have accurate expectations of development. As mentioned above, twenty five percent of the landowners expect to sell or develop their land within the next five years. There is a corresponding group of 25 percent of landowners who expect new residential development on adjacent sites with five years. The sensitive group with more than 100 acres has a proportion of 33 percent who expect new development within five years. Residents have an even higher proportion of 48 percent who expect new development. The seller/ developer group has the highest fraction of growth anticipation in the area with 53 percent.

Current zoning and land use controls were the least significant of the stated factors that could influence sale or development. An overwhelming majority in all owner groups indicate that current land use policies do not increase pressures to sell/develop land. Community capital improvements is a relatively significant factor when compared to the others but is still considered to encourage development by only a minority of landowners. These findings support the conclusions of Brown (1981) that metropolitan growth is primarily the result of long-term market forces.

Financial considerations obviously will have a significant impact on the seller/developer group. Monetary factors are substantially less important for the other groups as is shown in Table 6. Increases in property values and lower interst rates are the most significant factors for the seller/developer group. Their response is economically rational. 
The burden of property taxes is also considered significant by close to a majority of this group.

Overall, the burden of property taxes carries the most weight with the survey sample having a very slight majority disagreeing that heavy taxes could force a property sale. Participants in the FFOS Program are particularly worried about property taxes. It is not only obvious from their participation in the program but is also reflected in their survey responses. An equal number of FFOS participants agree with the property tax statement and disagree with it.

Another economic factor of land use is the productive resources which can be developed from the land. Most sites in West Greenwich are very difficult to farm. Table 7 shows the vast majority of owners use none or very little of their land for farming. The tough situation for farmers may be indicated by the presence of two intensively farmed parcels among the seventeen that make up the seller/developer group. Landowners in the FFOS group farm a greater percentage of land than the total sample and all other groups.

Timber production is more important to West Greenwich landowners. As Table 7 indicates, large land holders have the greatest proportion of high intensity timber production. A vast majority of all landowners use their wood for firewood and/or sale to the lumber mills. The timber market certainly has a big effect on the use of the land.

The ranking of factors which help the landowner retain his or her land in its present use was the most difficult task for completion by the survey respondents. It, therefore, had the greatest number of missing values. Many people either misunderstood the request or chose to rank only a couple of factors. Many others chose not to respond at all. 
Table 7. Percentage of Land in Rural Use

\begin{tabular}{|c|c|c|c|c|c|c|c|c|c|c|}
\hline Ownership Grouns & & & ricult & & & & & imber & & \\
\hline & 0 & $1-25$ & $26-50$ & $51-75$ & $76-100$ & 0 & $1-25$ & $26-50$ & $51-75$ & $76-100$ \\
\hline Total & 63 & 24 & 10 & - & 3 & 37 & 12 & 17 & 14 & 20 \\
\hline Residents & 48 & 33 & 11 & - & 7 & 35 & 15 & 12 & 19 & 19 \\
\hline $\begin{array}{l}\text { Long-term } \\
\text { owners }\end{array}$ & 61 & 26 & 13 & - & - & 41 & 4 & 9 & 14 & 32 \\
\hline $\begin{array}{l}\text { Large I.and } \\
\text { Holders }\end{array}$ & 45 & 45 & 9 & - & - & 9 & 9 & 9 & 27 & 46 \\
\hline FFOS & 48 & 29 & 14 & - & 10 & 27 & 18 & 18 & 18 & 18 \\
\hline $\begin{array}{l}\text { Seller/ } \\
\text { Developer }\end{array}$ & 62 & 19 & 6 & - & 12 & 38 & 19 & 31 & 6 & 6 \\
\hline $\begin{array}{l}\text { Owners against } \\
\text { more restrictions }\end{array}$ & 58 & 42 & - & - & - & 42 & 10 & 16 & 5 & 26 \\
\hline
\end{tabular}


Almost half of the landowners were not able to be included in the analysis of the important factors which encourage retention of present land use. With 55 percent responding correctly, however, we can still obtain a reasonable idea of which personal, economic and policy factors that could have influence on the landowner's decision to continue the present use of his or her land.

Table 8 shows the frequency of response for each factor, the mean response, and the overall rank-order that was determined by the total sample mean values. Landowners consider "sufficient growth management to maintain beauty of area" as the most significant factor. The other factors in decreasing order of importance are: steady employment; state income tax exemption; continued good relations with family; lower interest rates; continued good relations with neighbors; improved timber markets; state purchase of development rights to my property; comnunity capital improvements; and better prices for farm products. Table 9 displays the group means and rank of each factor according to its importance to each landowners group.

Another economic factor that could help retain the present use of the land is the return that is received by the owner in the form of rental income. This option is not utilized by many landowners in West Greenwich. Contracts to lease land for timber production have been arranged by only three percent of the owners. Another three percent rent housing. Arrangements for an agricultural lease has been made by one owner from the sample. There is also one owner who has a lease agreement for a commercial use.

Table 10 lists the significant correlation coefficients of the total response to influence of development factors on current land use. It 
Table 8. Landowner Ranking of Factors Which Could Help Retain Land In Its Present Use

(Total Sample)

\begin{tabular}{|c|c|c|c|c|c|c|c|c|c|c|c|c|c|}
\hline \multirow[b]{2}{*}{ Factors } & \multicolumn{11}{|c|}{ Response \% of Total } & \multirow[b]{2}{*}{ Mean } & \multirow[b]{2}{*}{ Rank } \\
\hline & 1 & 2 & 3 & 4 & 5 & 6 & 7 & 8 & 9 & 10 & $\begin{array}{l}\text { Missing } \\
\text { Values }\end{array}$ & & \\
\hline Better Farm Prices. & 6 & 3 & 4 & 3 & - & 4 & 4 & 7 & 7 & 16 & 45 & 6.816 & 10 \\
\hline Capital Improvements. & 4 & - & 4 & 6 & 9 & 6 & 6 & 7 & 9 & 3 & 46 & 6.054 & 9 \\
\hline Family Relations. & 9 & 9 & 4 & 3 & 6 & 12 & 6 & 1 & 4 & 1 & 45 & 4.632 & 4 \\
\hline $\begin{array}{l}\text { Relations with } \\
\text { Neighbors. }\end{array}$ & 1 & 6 & 12 & 4 & 7 & 6 & 9 & 9 & 3 & - & 44 & 5.179 & 6 \\
\hline $\begin{array}{l}\text { Lower Interest } \\
\text { Rates. }\end{array}$ & 3 & 6 & 7 & 12 & 12 & 3 & 9 & - & 3 & 4 & 42 & 4.975 & 5 \\
\hline $\begin{array}{l}\text { Better Timber } \\
\text { Markets. }\end{array}$ & 7 & 4 & - & 6 & 7 & 3 & 6 & 10 & 10 & 4 & 42 & 6.025 & 7 \\
\hline $\begin{array}{l}\text { State Income Tax } \\
\text { Exemption. }\end{array}$ & 12 & 4 & 6 & 10 & 3 & 4 & 4 & 6 & 4 & 1 & 45 & 4.526 & 3 \\
\hline $\begin{array}{l}\text { State Purchase of } \\
\text { Development Rights. }\end{array}$ & 6 & 10 & 3 & 1 & 3 & 1 & 4 & 9 & 4 & 13 & 44 & 6.053 & 8 \\
\hline Steady Employment. & 17 & 4 & 10 & 3 & 3 & 3 & - & 3 & 4 & 9 & 42 & 4.410 & 2 \\
\hline $\begin{array}{l}\text { Maintain Beauty } \\
\text { of Area. }\end{array}$ & 4 & 14 & 6 & 9 & 4 & 12 & 4 & 1 & 1 & 1 & 42 & 4.250 & 1 \\
\hline
\end{tabular}


Table 9. Group Means of Factors Which Could Help Retain Land in its Present Use

\begin{tabular}{|c|c|c|c|c|c|c|c|c|c|c|c|c|}
\hline Factors ${ }^{*}$ & Reside & ents & $\begin{array}{r}\text { Long } \\
\text { own } \\
\end{array}$ & $\begin{array}{l}\text {-term } \\
\text { ers }\end{array}$ & $\begin{array}{r}\text { Larg } \\
1 \text { and } h \\
\end{array}$ & olders & $\mathrm{F} F$ & $0 \mathrm{~S}$ & $\begin{array}{r}\text { Sel } \\
\text { deve }\end{array}$ & $\begin{array}{l}\text { er/ } \\
\text { oper }\end{array}$ & $\begin{array}{r}\text { Against } \\
\text { restrict } \\
\text { devel }\end{array}$ & $\begin{array}{l}\text { more } \\
\text { ions on } \\
\text { pment }\end{array}$ \\
\hline & mean & rank & mean & rank & mean & rank & mean & rank & mean & rank & mean & rank \\
\hline of area & 2.48 & 2 & 2.00 & 2 & 2.20 & 1 & 2.20 & 1 & 2.63 & 4 & 2.87 & 6 \\
\hline $\begin{array}{l}\text { Steady Employ- } \\
\text { ment }\end{array}$ & 2.75 & 5 & 2.92 & 5 & 2.30 & 2 & 2.92 & 6 & 2.25 & 1 & 2.69 & 4 \\
\hline $\begin{array}{l}\text { State income } \\
\text { tax exemption }\end{array}$ & 2.45 & 1 & 2.75 & 4 & 2.36 & 3 & 2.15 & 1 & 2.98 & 5 & 2.60 & 2 \\
\hline $\begin{array}{l}\text { Family rela- } \\
\text { tions }\end{array}$ & 2.55 & 4 & 2.48 & 3 & 2.64 & 4 & 2.93 & 7 & 2.33 & 3 & 2.53 & 1 \\
\hline $\begin{array}{l}\text { Lower interest } \\
\text { rates }\end{array}$ & 2.95 & 7 & 3.45 & 8 & 3.40 & 9 & 2.67 & 3 & 2.31 & 2 & 2.88 & 7 \\
\hline $\begin{array}{l}\text { Relations with } \\
\text { neighbors }\end{array}$ & 2.52 & 3 & 1.92 & 1 & 2.73 & 5 & 2.93 & 7 & 3.25 & 8 & 2.87 & 5 \\
\hline $\begin{array}{l}\text { Better timber } \\
\text { markets }\end{array}$ & 2.77 & 6 & 2.92 & 6 & 3.07 & 6 & 2.79 & 5 & 3.98 & 10 & 3.60 & 9 \\
\hline $\begin{array}{l}\text { State Purchase } \\
\text { of development } \\
\text { rights }\end{array}$ & 3.30 & 8 & 3.60 & 9 & 3.50 & 10 & 3.286 & 8 & 3.83 & 9 & 2.69 & 3 \\
\hline $\begin{array}{l}\text { Capital improve- } \\
\text { ments }\end{array}$ & 3.63 & 10 & 3.18 & 7 & 3.30 & y & 3.77 & 10 & 3.08 & 6 & 3.20 & 8 \\
\hline $\begin{array}{l}\text { Better farm } \\
\text { prices }\end{array}$ & 3.50 & 9 & 3.42 & 10 & 3.36 & 8 & 3.46 & 9 & 3.17 & 7 & 3.72 & 10 \\
\hline
\end{tabular}

* Factors are listed in order of importance according to their ranking by the total sample. 
Table 10. Significant Correlation Coefficients of Total Response to Influence of Development Factors on Current Land Use.*

\begin{tabular}{|c|c|c|c|c|c|c|c|c|c|}
\hline Factors & $\begin{array}{l}\text { Increase } \\
\text { in } \\
\text { Property } \\
\text { Value } \\
\end{array}$ & $\begin{array}{l}\text { Expect } \\
\text { to sel1 } \\
\text { within } \\
5 \text { years }\end{array}$ & $\begin{array}{l}\text { Lower } \\
\text { Interest } \\
\text { rates }\end{array}$ & $\begin{array}{l}\text { Capital } \\
\text { Improvements }\end{array}$ & $\begin{array}{l}\text { Zoning and } \\
\text { current } \\
\text { land use } \\
\text { control } \\
\end{array}$ & $\begin{array}{l}\text { Expect } \\
\text { Heirs to } \\
\text { Possess } \\
\text { Land } \\
\end{array}$ & $\begin{array}{l}\text { Annual } \\
\text { Income }\end{array}$ & $\begin{array}{l}\text { Percentage } \\
\text { of Agricul- } \\
\text { tural } \\
\text { Use } \\
\end{array}$ & $\begin{array}{l}\text { Bi-Serial } \\
\text { Corr } \\
\text { Scale-Item }\end{array}$ \\
\hline $\begin{array}{l}\text { Increase in } \\
\text { Property Value. }\end{array}$ & - & 0.5007 & 0.5303 & 0.2772 & 0.3431 & 0.3095 & -0.2456 & 0.3769 & 0.7566 \\
\hline $\begin{array}{l}\text { Expect to sell } \\
\text { within } 5 \text { years. }\end{array}$ & 0.5007 & - & 0.5990 & $\mathrm{n} \cdot \mathrm{s}$. & n.s. & 0.4375 & -0.4120 & 0.0528 & 0.5726 \\
\hline $\begin{array}{l}\text { Lower Interest } \\
\text { rates. }\end{array}$ & 0.5303 & 0.5990 & - & 0.4538 & 0.3347 & 0.2815 & -0.2993 & -0.2563 & 0.6950 \\
\hline $\begin{array}{l}\text { Capital Improve- } \\
\text { ments. }\end{array}$ & 0.2772 & n.s. & 0.4538 & - & 0.3782 & n.s. & n.s. & n.s. & 0.3916 \\
\hline $\begin{array}{l}\text { Zoning and Cur- } \\
\text { rent Land Use } \\
\text { Controls. }\end{array}$ & 0.3431 & n.s. & 0.3347 & 0.3782 & - & n.s. & n.s. & $\mathrm{n} \cdot \mathrm{s}$. & 0.5307 \\
\hline $\begin{array}{l}\text { Expect Heirs to } \\
\text { possess land. }\end{array}$ & 0.3095 & 0.4375 & 0.2815 & n.s. & n.s. & - & -0.3581 & $\mathrm{n} \cdot \mathrm{s}$. & 0.5561 \\
\hline Annual Income. & -0.2456 & -0.4120 & -0.2993 & n.s. & $\mathrm{n} \cdot \mathrm{s}$. & -0.3581 & - & n.s. & -0.3561 \\
\hline $\begin{array}{l}\text { Percentage } \\
\text { Agricultural } \\
\text { use. }\end{array}$ & 0.3769 & 0.0528 & -0.2563 & n.s. & $\mathrm{n} \cdot \mathrm{s}$. & n.s. & n.s. & - & 0.3720 \\
\hline
\end{tabular}

n.s.- not significant

* - Level of significance for students $t$ set at five percent 
measures the associations of the Likert statements, property and owner characteristics which have been assumed to have a relation with the propensity to sell or develop. The strength of the positive correlation for each variable with the "expect to seil/develop within five years" variable and the bi-serial correlation scale-item indicates the degree of validity for the assumptions made. The strength of the relationships is generally weak. Strong positive correlations are found concerning the relations between "Increases in property values may influence sale or development," "I expect to sell or develop within five years", and "Lower interest rates will encourage sale or development".

The expected relation of income with the other development factors is in error. The negative correlations suggest that people who agree that development factors may influence the orientation of their land use plans toward sale or development will tend to have a higher income than those who do not agree. The other variables in the table all have a positive association with the scale which suggests that they do have some direct relation with the entire group of variables and are a contributing factor to the propensity to sell or develop.

In comprising the landowner scale based on land use intentions, fifteen variables were considered as possibly significant. Seven of these variables were not included in Table 8 because very few significant correlations were found. Those few correlations that were statistically significant had little meaning for this analysis, e.g. the variable for age had only one significant correlation which was a very positive one with occupation which does not relate to this gudy.

The variables with few significant correlations were included in the scalogram analysis to determine if their operating characteristics worked 
according to the assumptions made. The effects of age on propensity to sell or develop is negligible as indicated by neutral and insignificant correlations and by a negative bi-serial correlation with the scale being -0.1895. The effects of occupation and retirement are both negligible for similar reasons. Since retirement makes up part of the development side of the occupational scale and few retired people have attitudes indicating sale or development, both variables are not strongly related to the development classification scheme used here. The bi-serial correlation scale-item for occupation is 0.0645 and it is 0.2310 for "retirement will increase pressures to sell/develop."

It is important to realize how this study determined the impacts of development factors. The analysis places landowners into categories according to their reported attitudes and feelings. Many times, behavior does not correspond with the attitudes and intentions of people. External forces can often alter behavior from what one would like. Retirement is not foreseen by many to be a time when a decision to sell or develop one's land is made, but personal factors may force that decision upon them. This study cannot estimate the likelihood of life cycle factors dominating intentions. Retirement is therefore considered to be a negligible development factor in its empirical analysis.

"The burden of property taxes" and the percentage of land used for timber production are also not important factors that indicate orientation towards sale or development. As already shown in Table 7, timber production is a concern of a wide variety of owners. The intensity of timber production can therefore not be used to discriminate developer types from conservationist types. It does have a positive relations with the scale though it is a weak one with a correlation of 0.1507 . Property taxes are not important to people who intend to sell or develop which is indicated by 
its low correlation of 0.0575 with the scale. The burden of property taxes is considered quite important by the landowners with low incomes which is clearly indicated by the high positive correlation of 0.4128 between income and response to "the burden of property taxes may pressure me to sell my property."

Though the variables for expectations of new residential development and "development of my neighbor's land may force me to sell or develop my land" had no significant correlation with the other development factors, they can be considered as moderately important for the landowner's intended land use. These two variables have positive correlations with the scale, which is 0.2762 for expectations of new development and 0.4268 for development of neighbor's land. Decisions to sell/develop or retain present land use will take into account how intensive development is on contiguous sites.

Overall, the fifteen development factors do not constitute a good scale. When the fifteen variables are sorted into various groups of twelve for Guttman scale analysis, the average coefficient of scalability is only equal to 0.2900 . The best set of scalable statements was found by item analysis and deduction. The group with the best discriminating charactertistics represent the importance of economic forces and market forces on landowner behavior. This group is comprised of the following variables: "Increase in property value may influence sale or development", "I expect to sell or develop my land within the next five years," "Lower interest rates will encourage me to sell or develop my land", and "I expect that my land will become the possession of my heirs". The coefficient of scalability for this group is equal to 0.6634 .

Table 11 shows the relative frequency of the three scales that 
Table 11. Landowner Classification (percent)

\begin{tabular}{|c|c|c|c|}
\hline Continuum & $\begin{array}{c}\text { Personal Development } \\
\text { Policy }\end{array}$ & $\begin{array}{l}\text { Community Development } \\
\text { Policy Preference }\end{array}$ & $\begin{array}{l}\text { Estimate of Potential } \\
\text { Land Development Status }\end{array}$ \\
\hline Preservationist & 37 & 22 & 11 \\
\hline Conservationist & 14 & 31 & 40 \\
\hline Moderate & 1.5 & 26 & 32 \\
\hline Promoter & 19 & 19 & 16 \\
\hline Developmentalist & 15 & 2 & 1 \\
\hline
\end{tabular}


were constructed to indicate how owners can be expected to react to development pressures and policy decisions. To classify the population of landowners who did not respond to the survery, an estimate was extropolated from the correlation analysis of the scale variables. Correlations coeficients were calculated for the two scales with the study's universal variables. Table 12 displays the positive associations that the three scales have with each other and with five property and owner characteristics. The variables not shown on the table all had slightly negative correlations with the scale for personal development policy and slightly positive correlations with the scale for community development policy.

The correlations suggest that the size, value, percent of marginal lands, surrounding land use, and scores for land use potential of surrounding area have 1ittle or no relation to what the intended land use policy of the owner will be and to what land use policies the owner may prefer. The evidence also suggests that participants in the FFOS Program, residence of owner, type of owner, length of ownership, and agricultural use of the land have some relation to choice of personal and community land use policies. The assumptions made concerning the variables listed In Table 12 are moderately supported by the correlation coefficients. 
Table 12. Significant Correlation Coefficients of Landowner Scales with Property and Owner Characteristics

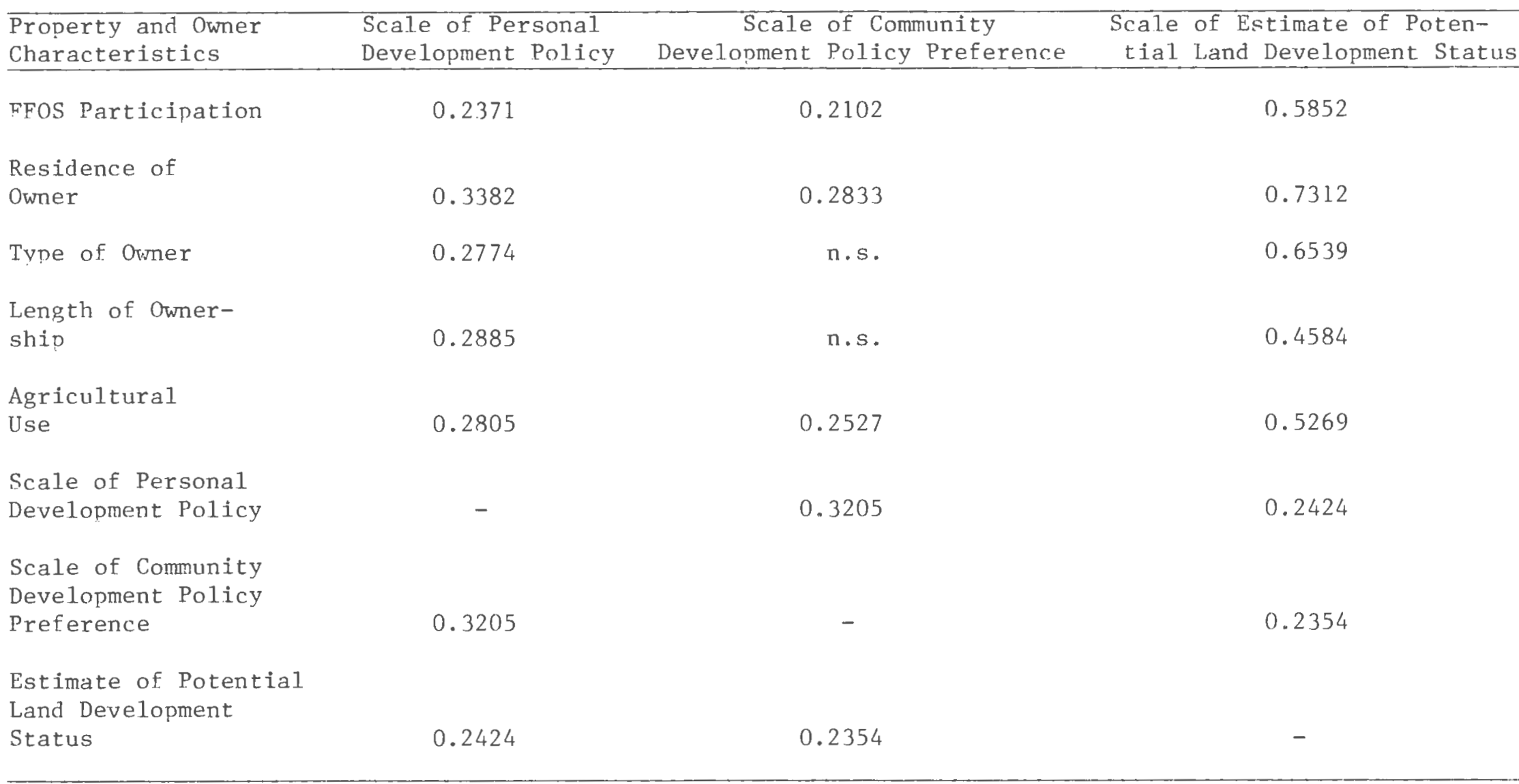




\section{EXPECTED DEVELOPMENT PATTERN}

The composite measure for each landowner was formed by summing up the values of FFOS, residency of owner, type of owner, length of ownership, and agricultural use of land and then dividing by five. This sample estimator and the scale devised directly from the survey for personal development policy indicate where patterns of development are likely to be located. Due to concern for donfidentiality, this information is presented by area rather than by parcel. Respect for privacy has also forced the information to be mapped for analysis by the researcher only. Map 3 shows the location of the areas described in the text.

Escoheag, the southwestern area of West Greenwich, is expected to maintain its rural character due to the presence of, Beach Pond State Park; ownership of land by non-profit organizations for recreational and educational purposes; private ownership of land for recreational uses; participation by several owners in the FFOS Program; use of several land parcels for hay and pasture; use of land for large rural residential estates; and the poor quality of road in area. There are, however, several investor type of landowners who may be waiting for market forces to allow for more intensive uses of their land. The Pine Top Ski Area, which has been left idle for several years, may be the key to the growth pattern of the area. It should become a profitable operation, if gas prices eventually force skiers to use local areas. This parcel has recently been transferred to a new owner and his plans for the 765 acre parcel remain unknown.

The northwestern section of West Greenwich known as Green should 


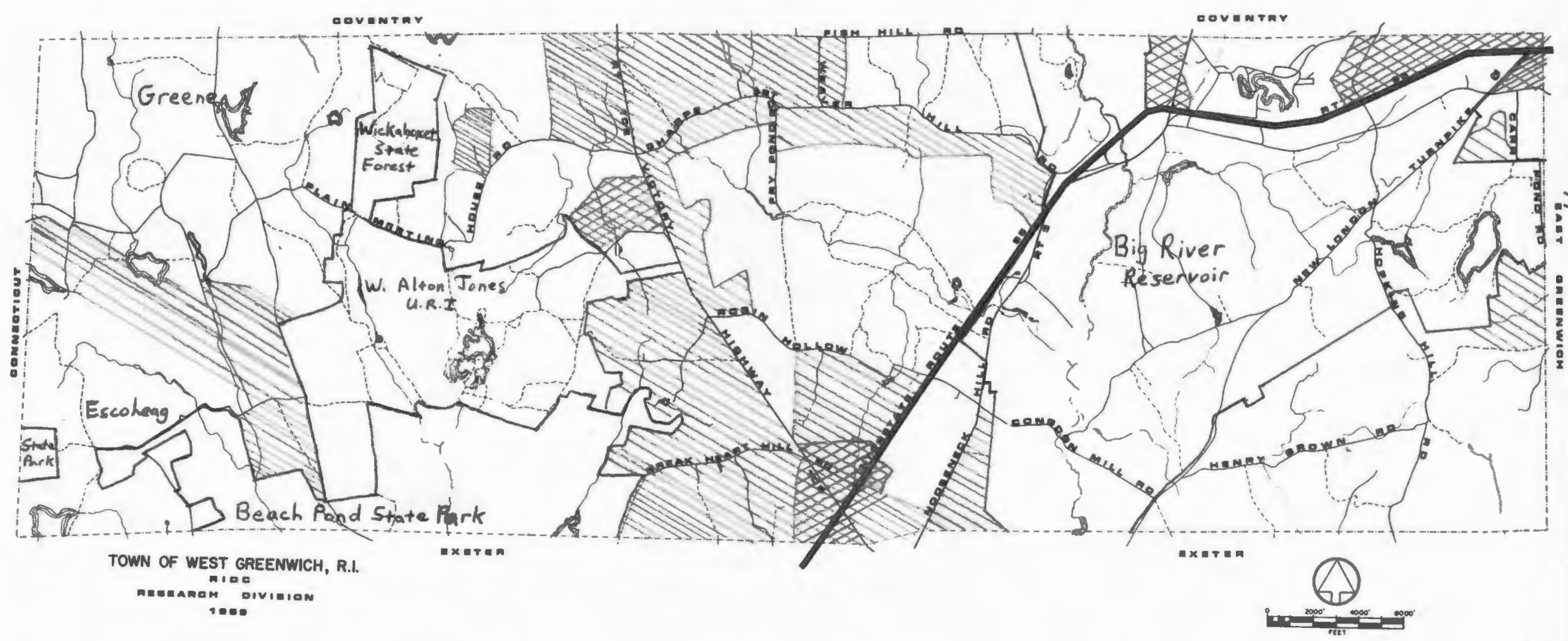

MAP 3. Development Pressures

Key $\square$ weak
$\square$ moderate
strong


also maintain its rural character. The area has some fine agricultural lands and timber stands that are likely to stay in rural use. The typical owner in this area owns a large parcel dedicated to rural uses and uses land for personal residential purposes. The land has been typically held for a long time and many of the owners participate in the FFOS Program. Changes in land use are not intended but could happen due to changes in family and life cycle factors.

Land west of the W. Alton Jones campus, east of Hudson Pond Road, and to the south of Liberty Hill Road has a mixture of ownership types. A large parcel in corporate ownership has good development potential. The intentions of this owner seem to be the sale of large lots for rural residential estates. If the land is subdivided into many small parcels for residential occupation, it would not conform to the pattern of large parcels with residential, agricultural, and silvicultural uses. Most of the landowners in this area are classified as conservationists. There are several landowners in area who are classified as moderates who may be persuaded to sell or develop if character of area changes.

Land that abuts Plain Meeting House Road, east of Wickaboxet State Forest, and west of Victory Highway is made up of many small parcels used as residences, several large parcels used for residences, production of Christmas trees, and general timber production, and two large parcels which will most likely be subdivided into residential sites. This area has quite a few parcels that were categorized by the Soil Conservation Service as being idle and ready to be converted for agricultural production. One of the large parcels will be converted to a small subdivision with covenants and restrictions preserving common property for open space in order to maintain environmental and scenic values. The other owner with a residential investment has not revealed his or her intentions. It is clear, 
however, that environmental constraints will limit the intensity of development on that site. The remaining large land owners in this area have declared their intentions to preserve rural use by their participation in the FFOS Program.

On Victory Highway, directly across from the West Greenwich Town Hall and the Town Library, there is a prime development site. The intentions of the partnership that owns this site is not known, but the site's location and physical characteristics make eventual development certain. The type of development will have an important effect on the town's goal of developing a town center.

Land south of Matteson Plain Road and west of Victory Highway has experienced development pressures. One large parcel was recently subdivided into thirteen home sites. Development will be incremental as owners eventually build houses on their lots. Most of the other owners in the area have relatively large parcels and were classified as moderates. Some of them may sell a section of their land or decide to subdivide. A few owners in this section of town are classified as conservationists. They use their land for residences and timber production and will most likely retain present use. Overall, it is probable that more development will take place in this area.

Land contiguous to the Route 95 interchange at Victory Highway is certainly affected by strong development pressures. It is a prime industrial site with good potential. Other companies could follow Coca-Cola's lead in taking advantage of transportation access and the availability of developable land. Owners in this area realize that more intensive development is required to obtain the highest and best use of their sites. 
The central area of West Greenwich, east of Victory Highway and est of Nooseneck Hill Road, is expected to have some residential development which will fill in the vacant areas next to existing residential sites along Sharpe Street, Weaver Hill Road, and Fish Hill Road. Only one major subdivision of approximately 100 acres is expected to be proposed. New development along Robin Hollow Road is expected to be for large rural residential estates. The forecast for relative stability of this area is based upon the landowner classifications and some important private land use decisions of landowners with residences on Fry Pond Road and Robin Hollow Road. A few months ago, a large estate of approximately 500 acres was purchased in nearly equal proportions by five abutting property owners with agreements to keep the land open for wildlife and to maintain character of the area. Another section of the estate was purchased by a conservationist type of landowner who intends to use it as a residence. One section of the estate which is on the south side of Robin Hollow Road and has about 100 acres in area is still for sale.

The southwest section of town is expected to retain its rural character into the foreseeable future. Timber production and ecological integrity of the area is very important to the landowners in this part of town. Most of the landowners here received classifications of conservationists. The environmental constraints of the area and the unpaved roads support the forecast for little development of area. Land to the north of Bates Trail may be influenced by market forces. Though the intentions of the landowners there is not known, they are classified as the type with developmentalist tendencies.

More development is expected in the northeast section of town. Land east of New London Turnpike and north of the Big River Reservoir site is available for residential development. One preservationist type 
landowner is the exception to several development minded owners and many sma11 land owners of two acre hose lots.

The land opposite from the Digital development is currently rural residential with most owners holding about ten acres of land. With the construction of the Route 95 interchange at Hopkins Hill Road, this land will become more suitable for industrial or commercial uses. There has been a proposal to rezone the area but long term owners are opposed to it. The possibility of windfall profits from Digital and the interchange may influence change to more intensive development.

The Lake Misknock area is the most intensively developed area of town. Land that could be available for development is owned by conservationist type landowners. Their commitment to retain their present use will be tested by strong development pressures. 
IMPLICATIONS FOR LAND POLICY

The empirical findings from the landowner survey provide a picture of landownership and land market dynamics that has very practical considerations for state and local land use policy. West Greenwich landowners are a heterogenous group with many contradictions that underscore the difficulty of devising policies that will effectively promote local economic development and preserve the rural uses of the land. Careful consideration must be given to the means of managing economic growth to ensure that attendant "side effects" are desirable or can be acceptably mitigated. Planning for rural development must look to the long term and attempt to identify the right kind of growth and the right kind of diversity.

Landowners are concerned about the kind of growth that Digital and its "side effects" may bring to the town. Important contradictions revealed by the landowner survey suggest that people expect Digital to have a favorable economic impact but do not think that it will necessarily bring about favorable community change. The findings that a majority of all groups think that the community will be enhanced by Digital contransts with the related findings that a majority of all groups see no personal benefits from the development and that a majority of all groups, except for the seller/developer group, perceive more development as doing damage to the attractiveness of the area. This contradiction reflects the concern for the rural quality of life.

Sufficient growth management to maintain beauty of area is the most important factor to help landowners retain their present land use. They are worried about the ugliness of sprawled development. Support for this anxiety is given by the empirical findings which suggest that development 
will be sprawled throughout most of the town due to the scattered presence of the investor/developer type of landowner. What to do about it is suggested by the landowner response to policy choices. Whereas a slim majority of landowners are in favor of more restrictions on development, an overwhelming majority think that land use regulations should not be more flexible. When compared with the response to satisfaction with current land use policies, which shows a majority to be undecided, the approved land use policy would increase with more rigorous controls. The type of controls will be the subject of debate but the need for some form of growth management is essentially agreed upon.

One form of growth management would be to direct new development into a rural center. All ownership groups have a majority who think that the future development of West Greenwich should be centralized. Incorporating the town center as the development node would require zoning changes, careful planning, innovative designs, state and local cooperation and public participation.

Strategies can be devised to direct growth to certain we11defined areas and limit the total amount of grovth in the community. Local authorities can influence investments in the area. The right kind of development and preferred land use intensity for each area can be determined by careful planning based upon an articulation of specific goals. Taken together, the development goals should reflect the community's future image of itself - how it imagines itself and wishes itself to be in the years to come.

If clearly delineated and strictly enforced, growth controls can be effective tools for controlling the timing and location of urban 
development in accord with the public purpose of preserving the rural auality of life. Designating particular areas for development and others for preservation must be implemented by a variety of techniques. Implementation of controls will begin a series of adjustments in land prices that generate pressures to relax or change the controls. Controls that effectively constrain where development may occur can reduce uncertainty about the timing and location of future development. Potential gains from land speculation will be reduced because less uncertainly will make developers more likely to purchase land directly from rural users. Development controls will contribute to higher land prices overlall since they restrict the supply of developable land.

As mentionea in the dicussion on land markets, some observers have suggested that investment activity itself can increase land prices above what they would otherwise be. For this to happen, investors would either have to assert monopolistic control or the speculative activity per se would have to cause higher prices. The latter supposition has already been disputed with the rationale that increased land values reflect normal appreciation and the presence of investors merely signals the rise in the competitive price of 1 and. This study also demonstrates that investors have limited market power. They own only 16 percent of the land parcels and about 20 percent of the land area in West Greenwich.

Taxation schemes which seek to discourage speculators by taxing capital gains from the short-term holding and sale of land are based on faulty premises. The tax will make speculative buying and selling less profitable. The evidence suggests that speculative buying is not a crucial factor in the land market of West Greenwich. This research shows that only 32 percent of the parcels owned by corporations and partnerships 
were acquired five years ago and that most 1 and investors in area hold property for a relatively long period. Land held for more than five or six years is typically exempt from typical "Speculation Taxes." Therefore, this tax scheme would have little effect on the behavior of most West Greenwich land investors. Furthermore, speculative taxes would not prevent the rise in land values resulting from the greater value of land in urban use than in rural use.

The empirical findings of this study suggest that large land holders and investor type owners may be influenced to retain rural use or ensure that development will be compatible with character of surrounding area by implementation of innovative zoning techniques and subdivision regulations. The weakness inherent in zoning for preserving rural uses is the fact that zoning regualtions can not unreasonably and excessively burden the use of property because it would be a violation of the Constitution's Fifth and Fourteenth Ammendments. Landowners may successfully challenge agricultural, open space, or large lot zoning as being unreasonabley burdensome, thereby leaving the town with the choice of rezoning the property or buying it.

"Compensatory Zoning" provides an alternative by which the owner is compensated for the value of his or her property's development value due to the zoning restrictions. Encouragement of the right kind of commercial and industrial development and promotion of efficient residential development would hopefully bring fiscal gains to the town that could offset the cost of "Compensatory Zoning." This scheme is similar to the outright purchase of development rights which is based on the concept that the owner possesses rights which can be separated from the land. Large land-holders and the seller/developer group have about an 
equal proportion of owners in agreement and disagreement with the proposed policy that the government should buy the development rights from landowners to preserve the rural environment. A majority of the overall sample disagrees with this policy. It received a ranking of eighth out of the ten factors which could help retain land in its present use. Separation of the development right from possession of the land is, however, more favorable to the group that would receive most of the impacts from policy designed to prevent development. Although an overwhelming majority of owners in the group of seller/deve1opers and large land holders are against more restrictions on development, they are neutral concerning the separation of development rights through compensation.

An apparent contradiction was found concerning the nature of the FFOS group. This groupd has the strongest majority of owners in favor of more restrictions on development and the weakest minority of owners who think the government should purchase development rights. This policy preference could indicate several attitudes of this group; they do not want the development rights to be permanently removed from their property; they think more restrictions is a cheaper and better way to control development; and/or they do not want this type of government program to preserve the rural environment because the funding mechanism may cause the benefits of their FFOS Program to be diminised. Whatever the reason, the FFOS group prefers restrictions and tax subsidies to help preserve rural qualities.

The tax subsidy of a state income tax exemption received a ranking as the third most important factor that would help retain land in its present use. With steady employment being the second most important factor, 
this study shows that income is a vital concern for the retention of rural land uses. A surprising finding is the relatively low reported incomes of major property owners. A state income tax exemption would especially help long term owners who are rich in land resources but relatively poor in amounc of annual income. A comprehensive income maintainence program should promote general economic viability for secure employment and provide tax subsidies so that poor and moderate income landowners are not forced to sell some or all of their property to obtain cash.

The reported incomes of the FFos groupd indicate that the program may have a redistributive effect that is not intended nor desirable. The basic assumption underlying the Act is that by the State providing property tax relief in the form of use value taxation, owners of undeveloped land will find it economically feasible to continue holding it. Unfortunately, the findings of this study suggest that the assumption has little evidence to substantiate it and much evidence to refute it. The unintended secondary effects of the program make its effectiveness very limited.

The FFOS group has a higher level of reported income than the overall sample. Many of the participants in the program can afford to pay property taxes assessed at the higher fair market value. Tax burdens will not be an important factor for these landowners when considering sale or development. Moreover, the subsidy given to FFOS participants must be offset by increased proverty taxes on non-participants and/or state subvention payments for the revenues foregone by operation of the program. This shift of the tax burden is inequitable because it requires the subsidy to be paid by taxpayers who have lower average incomes 
than the FFOS group. The higher property taxes for noncontracted lands is likely to be counterproductive as it would encourage development of these lands.

The finding that 70 percent of the FFOS Program's parcels in West Greenwich are experiencing very little development pressure reveals another weakness in the program. Preferential tax treatment is probably not necessary to preserve the rural use. With the contractual period arranged at ten or fifteen years, and no current development pressures on the land, the program may enable owners to merely reduce the holding costs of the land while maintaining rural use. When development pressures eventually become intense, then landowners may convert to urban use with little or no penalty. The program thus channels subsidy dollars to some owners who may be holding the land primarily for capital gains.

Scarce dollars should be allocated to where they will have the greatest impact in preserving agricultural and open space lands. The findings reported here indicate that greater selectivity should be exercised as to which parcels are eleigible for particination. Eligibility requirements should be based on income criteria, development potential and priorities for preserving farms, forest and open space. The operation should be coordinated with the state and local planning processes. Lands of the highest priority for preservation must be targeted for tax abatement. Conversely, lands of low priority should be excluded. Rising property taxes clearly force some owners to consider selling who would not sell otherwise. The survey indicates that 38 percent of the owners think that the burden of property taxes may force sale of their 1and. More strategically targeted preferential tax treatment could 
help these hard pressed owners to retain their land and would also preserve prime farm land and open space as well.

\section{CONCLUSION}

The limitations of current land policies reflect the very strong market forces converting the rural countryside to urban use. The opportunities for capital gains on the part of investors and rural landowners created by increasing demand for land will make growth inevitable in West Greenwich. The empirical findings suggest that the landowners have a wide array of compatible goals and a mixture of competing interests. To obtain the optimum complimentarity, West Greenwich must reassess its future and evaluate the changes.

Recognizing the limitations of conventional land policies, the people of West Greenwich will have to devise innovative techniques to preserve its rural character. The people have already shown their capabilities of reaching important private agreements to preserve open space. The public sector now needs the fullest amount of public participation in order to give practical expression to the public's self perceived interest. There are many ideas and views of what is "best." Fu11 participation and constructive leadership can serve as a means for giving order and focus to what would otherwise be a chaos of competing interests.

State planners and local policy makers must respond to the profile of land ownership provided by this research. A dialogue must be carried on with the whole community to determine the necessary tradeoffs in the best long-term interests of the community. West Greenwich can take advantage of the anticipated growth pressures by devising strategies to direct the form, location, and timing of urban growth. The overall direction of future land use change over time can be planned and implemented. 
Change can be like a double-edged sword. It can promote one value while another may suffer neglect. Solutions to problems of development must be negotiated with landowners in order to maintain the integrity of the area. By working in partnership with the landowners, the Town of West Greenwich can utilize market forces to improve its economic viability without destroying its rural qualities. 
APPENDIX A :

The Landowner Survey 


\author{
$294-6577$ \\ 495 Lafayette Rd. \\ N. Kingstown, R.I. 02852 \\ September 18, 1931
}

Dear West Greenwich Landowner,

I am a student in the Community Planning, and Area Development program at U.R.I. and I need your help. My experience in evaluating land use policies has convinced me that the considerations and intentions of landowners are not well understood by the people who make rules and regulations regarding land use. This major shortcoming has been an interest of mine that I finally develoned into a thesis research project. With your cooperation, I can provide important new insights for policy makers about how growth pressures may affect landholding behavior in a rural town.

Your town was chosen for study because of the opportunities and problems that must be addressed concerning, the impacts of Digital Equipment Corporation. What you do with the new circumstances will determine the character of Vest Greenwich. Knowledge of your objectives can be a vital factor in creating, fostering and preserving increased benefits in community life.

Please fill out the enclosed survey form. I am asking you for important information regarding your family, your property, your community, and the future plans for your land. Your responses will be kept strictly confidential. The survey form is coded with a master Iist of owners. This list will be destroyed when the data is compiled in an aggregate and anonymous form.

Completion of the survey form should take no longer than ten minutes of your time. You may actually enjoy it. If you can, please do it right now. Experience has shown that surveys stand a better chance of being returned when they are completed immediately upon receipt. Please call me if you have any questions or comments. Thank you very much for your time and cooperation. I shall pay you back by giving; the town more practical information for better land use plans.

Sincerely,

John C. Cronin 


\section{Frequency Distribution}

(percent)

Guide for responses to statements numbered one to twenty-two:

$$
\begin{aligned}
\text { SA } & \text { - Strongly agree } \\
\text { A } & - \text { Agree } \\
U & - \text { Undecided } \\
D & - \text { Disagree } \\
S D & - \text { Strongly disagree }
\end{aligned}
$$

1. The entry of Digital into West Greenwich will considerably enhance the community's well-being.

2. Increases in property values may influence me to sell or develop my property to reap financial gain.

3. More intensive development of. land will do serious damage to the attractiveness of the area.

4. The burden of property taxes may pressure me into selling my property.

5. I am satisfied with the town's current land use control policies.

6. Residential developments-will substantially increase due to the presence of Digital.

7. More intensive development of my neighbors' land may force me to sell or develop my land.

8. Community facilities and service (food stores, retail shops, professional and trade services) are adequate for the needs of my household.

9. I expect to sell or develop my land. within the next five years.

0. I am in favor of more rigorous land use controls which put more restrictions on development.

1. The lack of suitable moderate-income housing for rent is a problem in West Greenwich.

2. The lack of suitable moderate-income housing for sale is a problem. in West Greenwich.

3. Lower interest rates will encourage me to sell or develop my land.

4. If society wants to preserve a rural environment, then the government should buy the development rights directly from individual landowners. 
15. Retirement from my job will increase pressures on me to sell or develop my property.

$$
\begin{array}{llllll}
\frac{9}{\mathrm{SA}} & \frac{11}{\mathrm{~A}} & \frac{16}{\mathrm{U}} & \frac{44}{\mathrm{D}} & \frac{21}{\mathrm{SD}} \\
\frac{11}{\mathrm{SA}} & \frac{36}{\mathrm{~A}} & \frac{25}{\mathrm{U}} & \frac{16}{\mathrm{D}} & \frac{11}{\mathrm{SD}} \\
\frac{16}{\mathrm{SA}} & \frac{21}{\mathrm{~A}} & \frac{21}{\mathrm{U}} & \frac{26}{\mathrm{D}} & \frac{16}{\mathrm{SD}} \\
\frac{10}{\mathrm{SA}} & \frac{14}{\mathrm{~A}} & \frac{16}{\mathrm{U}} & \frac{36}{\mathrm{D}} & \frac{19}{\mathrm{SD}} \\
\frac{8}{\mathrm{SA}} & \frac{z}{\mathrm{~A}} & \frac{13}{\mathrm{U}} & \frac{55}{\mathrm{D}} & \frac{21}{\mathrm{SD}} \\
\frac{25}{\mathrm{CA}} & \frac{42}{\mathrm{~A}} & \frac{23}{\mathrm{U}} & \frac{6}{\mathrm{D}} & \frac{3}{\mathrm{SD}} \\
\frac{16}{\mathrm{SA}} & \frac{36}{\mathrm{~A}} & \frac{3}{\mathrm{U}} & \frac{6}{\mathrm{D}} & \frac{11}{\mathrm{SD}} \\
\frac{3}{\mathrm{SA}} & \frac{13}{\mathrm{~A}} & \frac{26}{\mathrm{U}} & \frac{32}{\mathrm{D}} & \frac{21}{\mathrm{SD}}
\end{array}
$$

3. I would like to see the population of West Greenwich in 1990 to be:

$\frac{5}{22}$ less than it is today.
$\frac{60}{3}$ moderately larger than it is today.
$\frac{11}{4}$ no opinion.

4. I expect the population of West Greenwich in 1990 to be:

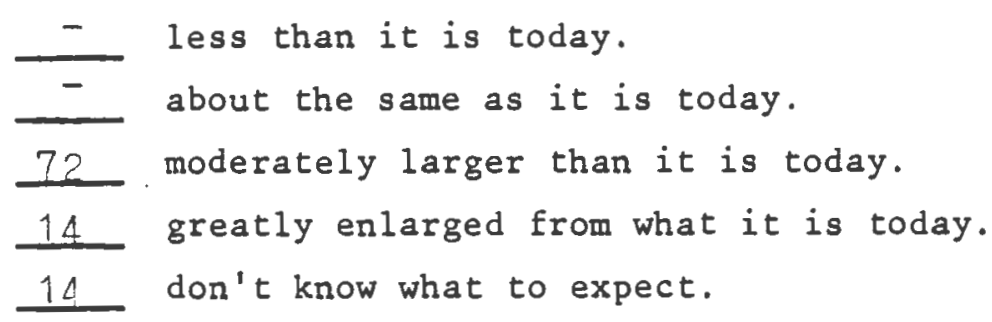

5. I do not expect new residential development on sites adjacent to my land until:

\begin{tabular}{l}
$\frac{5}{20}$ next year. \\
$\frac{33}{20}$ six to to five years from now. \\
$\frac{22}{2}$ nore than ten years from now. \\
\hline
\end{tabular}


26. Please rank from one to ten, in order of importance, those factors which could help you retain your land in its present use:

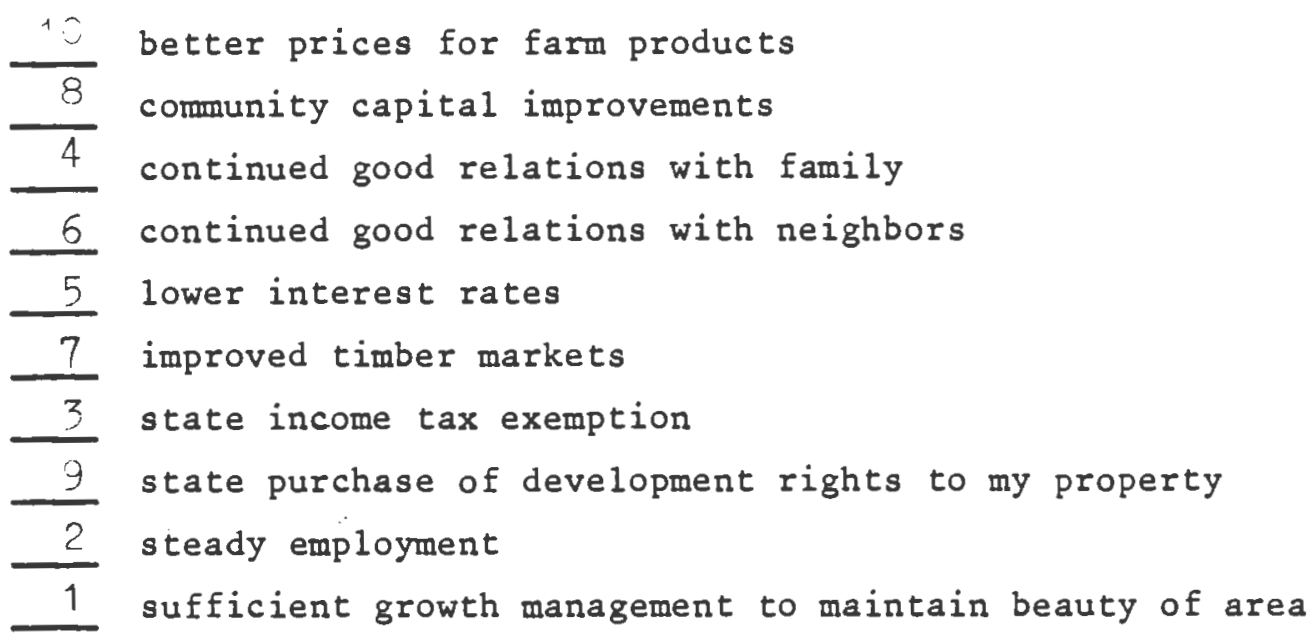

\section{Household Characteristics}

?7. Occupation of Head of Household -

18. Age of Head of Household

\begin{tabular}{|c|c|}
\hline 2 & 18 \\
\hline 10 & 25 \\
\hline 68 & 40 \\
\hline 21 & 65 \\
\hline
\end{tabular}

9. Approximate Annual Income of Household

\begin{tabular}{lll}
$\frac{20}{22}$ less than $\$ 10,000$ & $\frac{6}{7} \$ 50,000-\$ 59.000$ \\
$\frac{11}{11} \$ 20,000-\$ 19.000$ & $-\$ 29,000,000-\$ 69,000$ \\
$\frac{16}{11} \$ 30,000-\$ 39,000$ & $\frac{2}{2} \$ 70,000-\$ 79,000$ \\
\hline
\end{tabular}

0 . Do you lease your land to another? Yes No

If yes, please indicate type of use that the lease provides for:

$$
\text { residential }
$$

agricultural timber production

recreational

1. What percentage of your land is used for agricultural production?

2. What percentage of your land is used for timber production?

Thank you very much for completing this survey form. Please return it in the enlosed stamped self-addressed envelope as soon as possible. 
Alonso, William, 1964. "Location and Land Use". Cambridge, Mass: Harvard University Press

Barron, James C., and Thomson, James W. 1973. "Impacts of Open Space Taxation in Washington." Bulletin 772. Pullman, Washington: Washington Agricultural Experiment Station, College of Agricultur, Washington State University.

Bendavid-Val, Avrom. 1980. "Local Economic Development Planning: From Goals to Projects". Chicago: American Planning Association.

Blalock, Hubert M. 1972. "Social Statistics." New York: McGraw-Hill Book Company.

Brown, H. James: Phillips, Robyn S.; and Roberts, Neal A. 1981. "Land Markets at the Urban Fringe." Journal of the American Planning Association. April: 131-144.

Bureau of the Census. 1981. "U.S. Census of Rhode Island. Final Population and Housing Unit Counts." U.S. Dept. of Commerce. 1970-1980.

Chapin, S.F. 1962. "Urban Growth Dynamics." New York: John Wiley and sons.

Clawson, M. 1962. Urban sprawl and speculation in suburban land. "Land Economics 28, May: 99-111.

DeJong, Gordon F. and Sell, Ralph R. 1977. "Population Redistribution, Migration and Residential Preferences." Annals of AAPSS, 429, Jan.: $130-144$.

Denman, D.R. and Prodano Sylvio 1972. "Land Use: An Introduction to Proprietary Land Use Analysis". London: George Allen and Unwin Ltd..

Eriksen, E. Grodon. 1954. "Jrban Behavior." New York: The Macmillan Company.

Finkler, Ear1 L. and Popper, Frank J. 1981. "Finding Out who Owns the Land." Planning August: 19-22

Foster, Howard H. Jr. 1981 "Rural Centers as Development Nodes." Kingston, R.I.: University of Rhode Island Cooperative Extension Bulletin 214.

Foster, Howard H. Jr. 1981. "Projected Population Distributions and Land Use Potentials in Rhode Island." Kingston, Rhode Island: University of Rhode Island Cooperative Extension Bulletin 216.

Found, William C. 1971. "A Theoretical Approach to Rural Land Use Patterns." London: Edward Arnold Ltd.. 
Hansen, David E. and Schwartz S.I. 1975. "Landowner Behavior at the Rural-JJrban Fringe in Response to Preferential Property Taxation." Land Economics. November: 341-354.

Kaiser, E.J.; Massie, R.W.; Weiss, S.F.: and Smith, J.E. 1968. Predicting the behavior of predevelopment landowners on the urban fringe. "Journa1 of Urban Economics" 34. September: 328-333.

Kumekawa, Glenn; Barber, Brian; and Cushman, Mitche11. 1980. "Rural Development Strategies for the State of Rhode Island." Kingston R.I.: Intergovernmental Policy Analysis Program, University of Rhode Island.

Lassey, William R. 1977. "Planning in Rural Environments". New York: McGraw-Hill Book Company.

Lindeman, B. 1976. Anatomy of Land speculation. "Journal of the American Institute of Planners". 40, April: 142-152.

Lonsdale, Richard E.; and Seyler, H.L. 1979. "Nonmetropolitan Industrialization". New York: John Wiley and Sons., Inc..

Losch, A. 1954. "The Economics of Location." New Haven Conn: Yale University Press.

Massie, Ronald W. 1968. "Landowner Behavior: Factors Influencing the Propersities to Sell Land on the Urban Fringe." Chapel Hill, N.C.: Center for Urban and Regional Studies, University of North Carolina.

Milgrim, G. 1967. "The City Expands: A study of the Conversion on Land from Rural to Urban use," Philadelphia, 1945-62. Washington, D.C.: U.S. Government Printing Office.

Nie, Norman H.; Hul1, C. Hadlai; Jenkins, Jean G.; Steinbrenner, Karin; Bent, Dale H. 1975. "Statistical Package for the Social Sciences." New York: McGraw-Hill Book Company.

Providence Evening Bulletin 1980, 1981.

Providence Journal 1980, 1981.

Real Estate Research Corporation, 1974. "The Costs of Spraw1 (2 vols.)" Washington, D.C.: Government Printing Office.

Rhode Island Department of Community Affairs. 1972. "Comprehensive Community Plan for the Town of West Greenwich."

Rhode Island Department of Economic Development. "Basic Economic Statistics $1977-78$.

Rhode Island Department of Economic Development 1977. "West Greenwich Town Monograph." 
Rhode Island Statewide Planning Program. 1979. "Rhode Island Population Projections by County, City and Town." Technical Paper No. 83.

Sargent, C.A. 1970, Urbanization of a rural county. Reserach Bulletin 859. West Lafayette, Indiana: Purdue University.

Schaenman, Philip S.; and Muller, Thomas 1974. "Measuring Impacts of Land Development: An Initial Approach." Washington D.C.: The Urban Institute.

Schmid, A. Allan 1968. "Converting Land From Rural to Urban Uses." Baltimore: John Hopkins Press.

Soil Conservation Service. 1981. "Rhode Island Agricultural and Openlands". U.S. Department of Agriculture.

Strong, Ann L. 1966. "Factors Affecting Land Tenure in the Urban Fringe." Urban Land. November: 1-6.

Strong, Ann L. 1975. "Private Property and the Public Interest: The Brandywine Experience." Baltimore: John Hopkins Press.

Torgerson, Warren S. 1958. "Theory and Methods of Scaling." New York: John Wiley and Sons, Inc.

Van de Geer, John P. 1971. "Introduction to Multivariate Analysis for the Social Sciences." San Francisco: W. H. Freeman and Company.

Vidich, Arthur J. and Bensman, Joseph 1968. "Small Town in Mass Society." Princeton, N.J.: Princeton University Press.

Wallace, David A. (ed.). 1970 "Metropolitan Open Space." Philadelphia: University of Pennsylvania Press.

West Greenwich Tax Book. 1981.

West Greenwich Land Use Planning Maps. 1976.

West Greenwich Plat Maps. 1981.

Whyte, William H. 1968. "The Last Landscape." Garden City, New York: Doubleday.

Wolfe, M.R. 1967. "A Chronology of Land Tenure." The Town Planning Review. Jan.: 271-290. 
1. The length of unpaved streets is my own estimate which was deve1oped by simple measurement of these roads on the base map of West Greenwich.

2. West Greenwich residents are presently alarmed about the possibility of ground water contamination by the hazardous waste dump at the Picillo pig farm in Coventry. Some 15,350 drums of hazardous waste were secretly dumped until chemical fires and bad odors aroused the neighbors in 1979. Soil of dump site has been contaminated with PCBs (Polychlorinated biphenyls). The dump is classified by the EPA as one of the 100 worst in the U.S. and is therefore eligible for "Superfund" aid. The clean-up operation is being managed by the State Department of Environmental Management. Fears have been expressed that the dump is polluting ground water flowing toward the state's proposed Big River Reservoir and private wells in Coventry and West Greenwich, but the State Department of Enviornmental Management has found no evidence of this (Providence Journal, $10 / 16 / 81)$

3. The concept of motive is derived from a basic assumption of modern economic theory: "utility maximization" is the motivational foundation for action. The concept of complimentarity is derived from the theory of external diseconomics. External Economics are benefits that do not accure to the decision maker. Costs that are not borne by the decision maker are external diseconomics. Denman and Prodano (1972) have formulated a land use theory for proprietary land use analysis based upon the economic concepts of utility and externalities. Some of their ideas are used here. 
4. The discriminant analysis model that was used in this study (Kaiser et a1 1968) was able to classify 74.5 percent of the parcels correctly in Greensboro, but only classified 61 percent of the parcels correct1y in Winston-Salem.

5. The potential for development of the contiguous area surrounding each parcel was established by a simple technique of combining the factors which in my opinion were a positive influence on development. Each positive factor was given equal weight and simply summed up to give the variable a score.

6. Positive association with the Guttman scale indicates that the variable measures movement towards or away from the same single underlying object which in this study is the development of land and preference for land use policy. Negative association with the scale indicates that the variable can not be used as a measuring device for movement along a continuum.

7. The location of noncommitted idle lands that could readily be brought into agricultural production was taken from the Rhode Island Agricultural and Openlands Map and outlined on the ownership maps of West Greenwich which was drawn from this study.

8. The total survey sample is comprised of 68 landowners from the study universe of 177. There are 31 West Greenwich residents who responded to the survey and make up about 45 percent of the total sample. People who own parcels of more than 100 acres comprise $22 \%$ of the total survey sample. There are 26 long-term owners in the sample which comprise 38 percent of the total. FFOS participants represent 35 percent of the sample. Owners who expect to sell or develop their land within five years add up to 25 percent of the sample. Landowners who are not in favor of more 
rigorous land use controls which put more restrictions on development comprise 33 percent of the sample.

9. The State of Vermont imposes a land gains tax on up to 60 percent of gain realized from short-term sales of land. The law provides progressive exemptions for long-term holdings. The tax rate decreases according to the length of time the seller has held the land. After six years, sellers are exempt. 